\title{
FGF21 as a mediator of adaptive responses to stress and metabolic benefits of anti-diabetic drugs
}

\author{
Kook Hwan Kim ${ }^{1}$ and Myung-Shik Lee ${ }^{1,2}$ \\ ${ }^{1}$ Severance Biomedical Research Institute, and ${ }^{2}$ Department of Internal Medicine, Yonsei University College of \\ Medicine, 50 Yonsei-ro, Seodaemun-gu, Seoul 120-752, Korea
}

Correspondence should be addressed to M-S Lee

Email mslee0923@yuhs.ac

\begin{abstract}
Most hormones secreted from specific organs of the body in response to diverse stimuli contribute to the homeostasis of the whole organism. Fibroblast growth factor 21 (FGF21), a hormone induced by a variety of environmental or metabolic stimuli, plays a crucial role in the adaptive response to these stressful conditions. In addition to its role as a stress hormone, FGF21 appears to function as a mediator of the therapeutic effects of currently available drugs and those under development for treatment of metabolic diseases. In this review, we highlight molecular mechanisms and the functional importance of FGF21 induction in response to diverse stress conditions such as changes of nutritional status, cold exposure, and exercise. In addition, we describe recent findings regarding the role of FGF21 in the pathogenesis and treatment of diabetes associated with obesity, liver diseases, pancreatitis, muscle atrophy, atherosclerosis, cardiac hypertrophy, and diabetic nephropathy. Finally, we discuss the current understanding of the actions of FGF21 as a crucial regulator mediating beneficial metabolic effects of therapeutic agents such as metformin, glucagon/glucagonlike peptide 1 analogues, thiazolidinedione, sirtuin 1 activators, and lipoic acid.
\end{abstract}
Key Words
- FGF21
- stress
- adaptation
- metabolic disease
- energy metabolism

\section{Introduction}

All known organisms have the capability to maintain homeostasis in response to environmental challenges. The ability to modify gene expression is a fundamental organismal mechanism of adaptation to environmental stimuli. In particular, hormones secreted from specific organs are important mediators of these adaptive responses through autocrine, paracrine, and endocrine actions. For example, insulin and glucagon are wellknown adaptive hormones that control whole-body glucose balance in response to changes in nutritional status. Emerging evidence has suggested that fibroblast growth factor 21 (FGF21) could also be an endocrine hormone contributing to the metabolic homeostasis.
The FGF21 gene was cloned as the 21st member of the FGF family by Dr Nobuyuki Itoh's group in 2000 (Nishimura et al. 2000), and its biological function was first identified as a potent enhancer of glucose uptake by Dr Alexei Kharitonenkov's group at Lilly Research Laboratories in 2005 (Kharitonenkov et al. 2005). After this discovery, FGF21 has gained considerable attention as a key regulator in the maintenance of energy homeostasis and as a promising therapeutic molecule for the treatment of obesity and type 2 diabetes (T2D).

Numerous studies have suggested that FGF21 plays a crucial role in the control of glucose and lipid energy balance in response to changes of nutritional status, such

Published by Bioscientifica Ltd 
as starvation and feeding (Badman et al. 2007, Inagaki et al. 2007, Coskun et al. 2008, Potthoff et al. 2009). FGF21 is also important in the maintenance of body temperature by enhancing thermogenesis in response to cold exposure (Fisher et al. 2012, Lee et al. 2014a). In addition, FGF21 participates in the pathogenesis and treatment of various diseases such as diabetes associated with obesity, liver diseases, muscle atrophy, cardiovascular diseases, and kidney injury. Intriguingly, FGF21 can mediate the therapeutic benefits of several anti-diabetic compounds such as metformin, glucagon/glucagon-like peptide 1 (GLP1) analogues, thiazolidinedione (TZD), and sirtuin 1 (Sirt1) activators. Here, we highlight recent insights regarding the role of FGF21 as an adaptive hormone in response to various physiological or pathological conditions and as a mediator of the beneficial metabolic effects of several therapeutic agents (Fig. 1).

\section{The role of stress-induced FGF21 in physiological conditions}

\section{FGF21 and nutritional status}

FGF21 expression is regulated by nutritional status, and changes in the FGF21 level are important for adaption to changes of the nutritional balance such as deprivation or oversupply of macronutrients and changes of amino acid composition (Kim \& Lee 2014). Alteration of FGF21 expression in response to nutritional alteration was first reported in 2007 (Badman et al. 2007, Inagaki et al. 2007). In starved mice, FGF21 is induced in the liver, contributing to metabolic adaptation to the fasting state by enhancing ketogenesis and $\beta$-oxidation in the liver. An increase of serum FGF21 level after fasting has been also observed in healthy human individuals (Galman et al. 2008). Fasting-induced hepatic FGF21 expression is mediated by the peroxisome proliferator-activated receptor alpha (PPAR $\alpha$; Badman et al. 2007, Inagaki et al. 2007), CREBH (Lee et al. 2011, Kim et al. 2014a), and Sirt1 (Li et al. 2014). Increased FGF21 also plays an important role in the regulation of fasting glucose levels by enhancing gluconeogenesis via upregulation of the hepatic PPAR $\gamma$ coactivator 1 alpha (PGC1 $\alpha$; Potthoff et al. 2009). Indeed, a recent study has shown that FGF21, produced in the fasted liver, enters into the brain and activates hypothalamic-pituitary-adrenal axis, leading to the enhancement of hepatic PGC1 $\alpha$ expression and gluconeogenesis (Liang et al. 2014). These results suggest that FGF21 coordinates an adaptive response to fasting via liver-brain axis.
In addition to its role in fasting, FGF21 has been reported to enhance insulin-stimulated glucose uptake under acute refeeding conditions (Markan et al. 2014). The serum FGF21 level was increased during the early stage of refeeding in mice, when the insulin level was also elevated. Importantly, liver-specific Fgf21 knockout $\left(F g f 21^{\Delta \text { hep }}\right)$ mice exhibited reduced serum FGF21 levels in both fasting and early refeeding and displayed aggravation of fasting-induced glucose intolerance, whereas these findings were not observed in adipose tissue-specific $F g f 21$ knockout $\left(F g 21^{\Delta \mathrm{Ad}}\right)$ mice (Markan et al. 2014). These results suggest that the liver, but not adipose tissue, is a primary organ producing FGF21 during fasting and acute refeeding and that FGF21 acts as an insulin sensitizer to enhance insulin-stimulated glucose uptake during the early refeeding period. In addition to complete nutrient deprivation, a 50\% food restriction causing malnutrition has been reported to increase serum FGF21 levels in mice (Kubicky et al. 2012). Fgf21 knockout $\left(\mathrm{Fg} f 21^{-1-}\right)$ mice were resistant to malnutrition-induced reduction of bone growth (Kubicky et al. 2012), suggesting that FGF21 is an important regulator of skeletal homeostasis as well as liver and adipose tissue. In contrast to malnutrition, caloric restriction without malnutrition did not result in FGF21 induction in mouse or human subjects (Zhang et al. 2012, Kim et al. 2013a, Lips et al. 2014). Moreover, caloric restriction-induced metabolic changes were not different between $\mathrm{Fg} 221^{-1-}$ and $\mathrm{Fg} 221^{+/+}$mice (Kim et al. 2013a), suggesting that FGF21 does not mediate the effects of caloric restriction on energy metabolism.

An increasing body of evidence suggests that FGF21 expression is regulated by changes in specific macronutrients. After feeding a ketogenic diet with low carbohydrates and high fat, mimicking a fasting state, FGF21 was induced in the liver of mice in an PPAR $\alpha$ dependent manner; consequently, increased FGF21 contributes to the enhancement of $\beta$-oxidation and ketogenesis caused by a ketogenic diet (Badman et al. 2007). In parallel, ketogenic diet-fed $F g f 21^{-1-}$ mice showed impaired adaptation to ketosis (Badman et al. 2009). A protein-restricted (low protein) diet has been also reported to increase hepatic FGF21 expression in mice through general control nonderepressible 2- and PPAR $\alpha$ dependent pathways. An increase in serum FGF21 levels was also observed in human subjects after a low protein diet (Laeger et al. 2014). The effects of a low protein diet on the enhancement of energy expenditure and decrease of fat mass were partially diminished in $F g f 21^{-1-}$ mice compared to control mice, suggesting the importance of FGF21 induction in whole-body adaption to low protein

Published by Bioscientifica Ltd. 


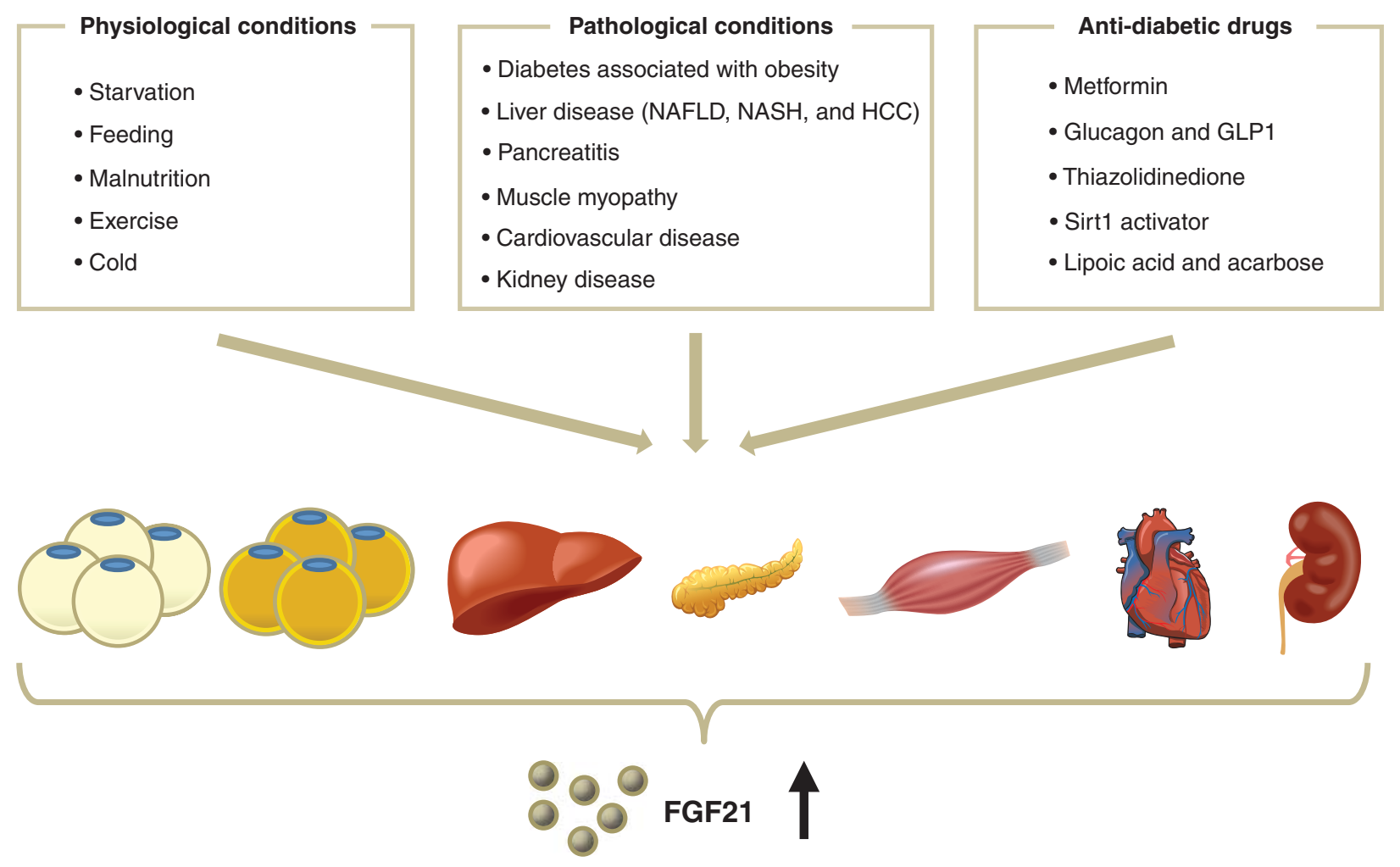

Local and systemic actions in multiple target organs

Adaptive and protective role in response to diverse stressful conditions

A mediator of beneficial metabolic effects of anti-diabetic drugs

Figure 1

Functional role of fibroblast growth factor 21 (FGF21) secreted from multiple organs in response to diverse stresses or stimuli. FGF21 expression is induced in multiple major organs, including white/brown adipose tissue, liver, pancreas, skeletal muscle, heart, and kidney, in various physiological and pathological conditions. FGF21 levels are also increased by several antidiabetic drugs or compounds. Consequently, elevated FGF21 plays an

intake (Laeger et al. 2014). Intriguingly, the serum FGF21 level and hepatic FGF21 expression were not increased in mice with a 50\% reduction in food intake without changes of protein intake (Laeger et al. 2014). Furthermore, FGF21 induction in mice fed a ketogenic diet was not attenuated by carbohydrate supplements (Laeger et al. 2014), implying that the increase in FGF21 during food restriction and the ketogenic diet appears to be primarily driven by low protein intake rather than by reduced carbohydrate intake. A high-fat diet (HFD) has been also reported to cause hepatic FGF21 induction in mice (Muise et al. 2008, Fisher et al. 2010). In this process, free fatty adaptive role in response to diverse stressful conditions and acts a mediator of beneficial metabolic effects of anti-diabetic drugs through local and systemic actions in target organs. NAFLD, nonalcoholic fatty liver disease; $\mathrm{NASH}$, nonalcoholic steatohepatitis; HCC, hepatocellular carcinoma; GLP1, glucagon-like peptide 1 .

acids appear to stimulate FGF21 gene expression in PPAR $\alpha$-dependent (Mai et al. 2009) or -independent pathways (Tanaka et al. 2015). Collectively, these results indicate that the induction of FGF21 in response to changes in macronutrient ingestion is important for metabolic adaption.

In addition to changes in the quantities of macronutrients, changes of amino acid composition in proteins and monosaccharide composition in carbohydrates influence FGF21 expression. Methionine restriction (approximately a $75-80 \%$ decrease of methionine intake) has been reported to extend the lifespan and lead to decreased

Published by Bioscientifica Ltd. 
fat mass and improved insulin sensitivity in rodents, probably by enhancing $\beta$-oxidation (Orentreich et al. 1993, Hasek et al. 2010). Importantly, methioninerestricted mice showed increases in the hepatic FGF21 expression and serum FGF21 level, accompanied by attenuation of obesity- or age-related insulin resistance (Ables et al. 2012, Lees et al. 2014). These results suggest that FGF21 may mediate beneficial metabolic effects of methionine restriction. However, metabolic effects of methionine restriction in $\mathrm{Fgf} 21^{-1-}$ mice remain to be determined. Complete deprivation of a specific amino acid also affects FGF21 gene expression. Several studies have suggested that FGF21 was induced by the eukaryotic translation initiation factor 2 alpha (eIF2 $\alpha$ )-activating transcription factor 4 (ATF4)-dependent pathway in the liver but not in adipose tissue or skeletal muscle of mice fed a leucine-deficient diet (De Sousa-Coelho et al. 2013, Kim et al. 2013a). Importantly, the enhanced glucose tolerance and reduced fat mass observed in WT mice fed a leucine-deficient diet were not shown in $\mathrm{Fg} 2 \mathrm{1}^{-1-}$ mice, suggesting that hepatic FGF21 acts as a critical mediator of the changes in whole-body energy metabolism in response to amino acid deficiency (De Sousa-Coelho et al. 2013, Kim et al. 2013a). Saccharides also influence FGF21 gene expression. In line with FGF21 induction in the livers during refeeding of mice (Markan et al. 2014), glucose was shown to directly induce FGF21 gene expression in hepatocytes in vitro through activation of the carbohydrate response element binding protein (Iizuka et al. 2009, Uebanso et al. 2011). A recent study has shown that fructose ingestion also acutely increased circulating FGF21 levels in humans (Dushay et al. 2015), suggesting that FGF21 may play a role in the metabolism of fructose or other monosaccharides, as well as glucose. A fundamental physiological role of FGF21 in individual carbohydrate metabolism remains to be clarified.

\section{FGF21, cold exposure, and exercise}

Heat production is important in the maintenance of body temperature in response to cold exposure. Thermogenesis in brown adipose tissue (BAT) is a critical component of heat production. Emerging evidence has suggested that white adipose tissue (WAT) browning, conversion of WATto BAT-like tissues, participates in the regulation of the body temperature (Harms \& Seale 2013). It has been reported that FGF21 is induced in BAT and WAT of mice and humans in an adaptive response to cold exposure (Fisher et al. 2012, Lee et al. 2014a), and thermogenic stimuli such as norepinephrine induce FGF21 gene expression in BAT via activation of the p38 $\alpha$-ATF2 axis (Hondares et al. 2011). Importantly, Fgf $21^{-1-}$ mice had decreased core temperatures after cold exposure compared to control mice, due to an impaired browning (Fisher $e t a l$. 2012). Thyroid hormones (THs), another thermogenic inducer, have been also reported to increase FGF21 gene expression in adipose tissue (Adams et al. 2010). However, the effect of TH on energy expenditure was not different between $\mathrm{Fg} f 21^{-/-}$and $\mathrm{Fg} f 21^{+/+}$mice (Domouzoglou et al. 2014), suggesting that FGF21 regulates adaptive thermogenesis in cold environments but not that after $\mathrm{TH}$ treatment.

In addition to cold exposure, acute or chronic exercise has been reported to increase circulating FGF21 levels in mice and humans (Cuevas-Ramos et al. 2012, Kim et al. $2013 b$ ). While contradictory data have been reported (Lee et al. 2014a), FGF21 might act as a mediator of the metabolic improvement by exercise. Consistently, recent data showed that enhancement of glucose tolerance by exercise was diminished in $F g f 21^{-1-}$ mice. Furthermore, exercise-induced AMP-activated protein kinase (AMPK) activation was markedly reduced in the skeletal muscle of Fgf $21^{-1-}$ mice compared to control mice, suggesting that FGF21 mediates the beneficial effects of exercise on glucose intolerance (Loyd et al. 2014). Thus, all of these studies indicate that FGF21 is a crucial player in the physiological adaption to cold and exercise.

\section{The role of stress-induced FGF21 in pathological conditions}

\section{FGF21 and diabetes associated with obesity}

FGF21 levels are paradoxically increased in the serum of obese diabetic mice or human subjects with T2D and obesity (Chavez et al. 2009, Fisher et al. 2010). This increase of serum FGF21 in obesity is probably due to the upregulation of FGF21 gene expression in the liver and adipose tissue (Fisher et al. 2010). While the liver rather than adipose tissue primarily produces FGF21 during fasting (Markan et al. 2014), it is unclear which of the liver or adipose tissue is the main producer of FGF21 in obesity. Considering the pharmacotherapeutic effects of FGF21, obesity-mediated FGF21 induction may be an adaptive mechanism to metabolic derangement associated with obesity. In line with this notion, HFD-fed $F g f 21^{-1-}$ mice showed aggravated glucose intolerance compared to HFD-fed $F g f 21^{+/+}$mice (Assini et al. 2015), although other investigators reported no difference of glucose intolerance between in $\mathrm{Fgf} 21^{-/-}$mice and $\mathrm{Fgf} 21^{+/+}$

Published by Bioscientifica Ltd. 
mice fed HFD (Fisher et al. 2010, Adams et al. 2013a). In parallel, leptin-deficient $o b / o b$ mice exhibited aggravated glucose intolerance and insulin resistance when Fgf21 was genetically disrupted (Kim et al. 2015). Thus, FGF21 may act as a compensatory signal to mitigate metabolic stresses due to obesity.

In obesity, FGF21 signaling has been reported to be impaired in major metabolic organs, including pancreatic islets, liver, and WAT (Fisher et al. 2010, So et al. 2013). Based on these findings, we speculate that obesity-related endogenous FGF21 induction alone is not sufficient to overcome impaired FGF21 signaling or FGF21 resistance. Administration of exogenous FGF21 and FGF21 mimetics improves glucose tolerance or insulin sensitivity in diabetic rodents and monkeys (Coskun et al. 2008, Xu et al. 2009, Wu et al. 2011, Foltz et al. 2012). Two recent papers have shown that an engineered FGF21 variant (LY2405319) ameliorates metabolic parameters in obese human subjects with T2D as well as diabetic monkeys (Adams et al. 2013b, Gaich et al. 2013). Especially, LY2405319-received T2D subjects showed a significant decrease of body weight and fasting insulin levels and the improvement of dyslipidemia including reduced LDL cholesterol and increased HDL cholesterol levels compared to placebo-treated subjects (Gaich et al. 2013). The glucose lowering effect of LY2405319 was also observed, while statistical significance was marginal (Gaich et al. 2013).

These pharmacological effects of FGF21 and its mimetics are attributable to the action on various metabolic target organs, such as adipose tissue, brain, liver, and pancreatic $\beta$ cells (Owen et al. 2015). Several studies have shown that FGF21 enhances insulin-induced glucose uptake and thermogenesis in adipose tissue (Kharitonenkov et al. 2005, Xu et al. 2009). In obese mice with whole-body deletion of $\beta$-klotho, a co-receptor for FGF21, the metabolic effects of FGF21 such as enhancement of energy expenditure or glucose tolerance and decrease of fat mass were diminished (Adams et al. 2012). Notably, these beneficial effects of FGF21 were also reduced in obese mice lacking $\beta$-klotho in adipose tissue or the brain (Ding et al. 2012, Owen et al. 2014). Furthermore, hepatic FGF21 actions such as alleviation of steatosis and suppression of hepatic glucose production were less pronounced in these mice, suggesting indirect FGF21 action on the liver. These findings suggest that both adipose tissue and the brain are major targets of systemic actions of FGF21 in metabolic improvement, although direct repressive effects of FGF21 on gluconeogenesis and lipogenesis in the liver have also been reported (Zhang et al. 2011, Kong et al. 2013). The importance of FGF21 action in adipose tissue has been also inferred from reduction of FGF21-mediated metabolic improvement in adiponectin knockout $\left(\right.$ Adipoq $^{--}$) mice (Holland et al. 2013, Lin et al. 2013).

Additionally, FGF21 increases insulin content in pancreatic $\beta$ cells and partially protects islets from glucolipotoxicity and cytokine-induced apoptosis (Wente et al. 2006). Chow-fed $F g f 21^{-1-}$ mice showed impaired glucose-stimulated insulin secretion (GSIS), probably due to a lack of FGF21 action-inhibiting growth hormone (GH) signaling in $\beta$ cells, and also displayed insulin resistance due to the increased $\mathrm{GH}$ signaling in insulin target tissues (So et al. 2015). Given that GH reportedly induces FGF21 gene expression (Chen et al. 2011, Yu et al. 2012), endogenous FGF21 induction may be a compensatory mechanism to alleviate insulin resistance induced by chronic GH treatment. In contrast, we have observed no difference in GSIS or insulin levels in the Fgf $21^{-1-}$ mouse strain (Kim et al. 2015). Further study is needed to evaluate the effect of endogenous FGF21 on the pancreatic islet function. Taken together, these results suggest that FGF21 acts as a therapeutic agent for the treatment of T2D associated with obesity via its pleiotropic actions in diverse metabolic organs.

Several studies have suggested that FGF21 exerts its metabolic beneficial effects through the regulation of other hormones. As previously described, FGF21 increases the production of insulin and adiponectin in pancreatic $\beta$ cells and adipose tissue respectively (Wente et al. 2006, Holland et al. 2013, Lin et al. 2013). It has been also reported that FGF21 reduces circulating glucagon levels in obese mice (Kharitonenkov et al. 2005). Given the role of glucagon in the aggravation of hyperglycemia through enhancing hepatic glucose production, glucagon could be a mediator for in vivo effect of FGF21. In addition, FGF21 is able to exert therapeutic effects in an insulin-dependent manner. While the effect of FGF21 on glucose lowering was still preserved in liver-specific insulin receptor knockout mice, the suppressive effects of FGF21 on circulating cholesterol and hepatic triglycerides were diminished in these mice (Emanuelli et al. 2014). These results suggest that FGF21 ameliorates hyperglycemia independent of insulin action in the liver of obese mice but affects hepatic lipid metabolism in an insulin-dependent manner. Given the metabolic action of insulin in various tissues, investigations on the relationship between FGF21 and insulin signaling in adipose tissue and the brain will also be of interest.

Published by Bioscientifica Ltd. 


\section{FGF21 and liver disease}

FGF21 is implicated in various liver diseases such as nonalcoholic fatty liver disease (NAFLD), nonalcoholic steatohepatitis (NASH), and liver cancer. Several studies have suggested that FGF21 was increased in the serum and liver of human subjects with NAFLD, and its level was correlated with hepatic triacylglycerol (TG) content (Dushay et al. 2010, Li et al. 2010). Molecular mechanisms underlying FGF21 induction in NAFLD have been recently identified (Jiang et al. 2014, Kim et al. 2015). Endoplasmic reticulum (ER) stress, which is implicated in the development and progression of NAFLD, appears to be responsible for FGF21 induction. Increased gene expression of both ER stress markers and FGF21 was observed in the livers of mice with steatosis or in those of human subjects with NAFLD (Jiang et al. 2014, Kim et al. 2015). Moreover, ER stressors are able to directly induce FGF21 gene expression in hepatocytes in vitro and in mouse livers in vivo. Consistently, ER stress-induced hepatic FGF21 expression was diminished in mice with the deletion of the inositol-requiring 1 alpha (Ire1 $\alpha$ ) gene (Jiang et al. 2014) or with Ser51Ala mutation of the Eif $2 \alpha$ gene in the liver (Kim et al. 2015). These results suggest that the IRE1 $\alpha$-X-box binding protein 1 axis or the eIF $2 \alpha-$ ATF 4 axis is an important signaling pathway in ER stress-induced FGF21 expression. Furthermore, chemicalinduced increases of ER stress marker gene expression and lipid accumulation in the livers of mice were reduced by recombinant FGF21 administration (Jiang et al. 2014) and in the livers of tetracycline-inducible $F \& 21$ transgenic mice (Kim et al. 2015). Fg $21^{-1-}$ ob/ob mice also had an increased expression of ER stress marker genes and aggravated liver injury compared to $\mathrm{Fg} f 21^{+/+}$ob/ob mice (Kim et al. 2015). Taken together, these results suggest that FGF21 plays a role in the adaptive response to ER stress induced by a pharmacological ER stressor or NAFLD.

In addition to NAFLD, FGF21 participates in the development and progression of NASH induced by a methionine-choline deficient (MCD) diet (Fisher et al. 2014). In mice fed an MCD diet, the serum FGF21 level was elevated, probably due to an increase in FGF21 expression in the liver but not in other organs. $F g f 21^{-1-}$ mice fed the MCD diet showed increased progressive steatohepatitis and hepatic fibrosis compared to control mice. Furthermore, $F g f 21^{-/-}$mice showed aggravated hepatic peroxidative damage, probably due to the elevation of free fatty acids caused by reduced activity of acyl CoA synthetases, which convert long-chain fatty acids to acyl CoAs. Another $\mathrm{Fg} / 21^{-1-}$ mouse strain also displayed increased lipid accumulation and ER stress response after an MCD diet (Tanaka et al. 2015). Indeed, FGF21 administration or FGF21 overexpression ameliorated MCD diet-induced metabolic derangements (Fisher et al. 2014). Thus, FGF21 induction in NASH may be a physiologic adaptation to hepatic stress responses, and FGF21 may be a promising therapeutic agent for the treatment of NAFLD or NASH.

NAFLD and NASH are risk factors for the development and progression of hepatocellular carcinoma (HCC; Michelotti et al. 2013). It has been reported that hepatic FGF21 expression was increased in diethylnitrosamine (DEN)-induced liver tumors and in livers of humans with HCC (Yang et al. 2013). Furthermore, Fgf21 transgenic mice showed a delayed appearance of DEN-induced liver tumors, although the incidence and burden of HCC were similar between $F g f 21$ transgenic and control mice (Huang et al. 2006). These findings suggest that FGF21 induction may be an adaptive mechanism to protect or delay the development and progression of liver cancer. Notably, an Fgf21 transgenic mouse strain in this study did not show reduced body weight, in contrast to other $F g f 21$ transgenic mouse strains. This discrepancy is probably due to a difference in mouse background (FVB vs C57BL/6) or a difference in serum FGF21 concentration between mouse strains. Further studies are needed to evaluate the fundamental role of FGF21 in hepatic carcinogenesis.

Liver is a primary organ to detoxify diverse toxic chemicals. It has been reported that FGF21 expression is increased depending on the aryl hydrocarbon receptor in the liver of mice after administration of 2,3,7,8-tetrachlorodibenzo-p-dioxin (TCDD), a highly toxic and carcinogenic chemical (Cheng et al. 2014). Fgf21 ${ }^{-1-}$ mice were susceptible to TCDD-induced mortality compared to control mice (Cheng et al. 2014), suggesting that FGF21 induction may be a protective signal against toxin-induced injury. It remains to be determined whether FGF21 regulates activity and expression of the detoxification enzyme or whether this action exerts a protective effect against toxin-induced injury.

\section{FGF21 and pancreatitis}

It has been reported that FGF21 is expressed in pancreatic acinar and islet cells (Wente et al. 2006, Johnson et al. 2009). Several studies have shown that FGF21 modulates the development and progression of pancreatitis, a known risk factor for pancreatic cancer (Johnson et al. 2009, 2014). In mice with cerulein-induced acute pancreatitis, FGF21 expression was increased in acinar cells but not in islet cells. Importantly, pancreatic inflammation and fibrosis were increased in $\mathrm{Fg}_{\mathrm{S}} 21^{-/-}$mice compared to control mice

Published by Bioscientifica Ltd. 
and, conversely, were decreased in Fgf21 transgenic mice (Johnson et al. 2009). Furthermore, FGF21 expression was markedly reduced in acinar cells of Mist1 knockout mice showing early events of pancreatitis such as the premature activation of digestive enzymes and acinar disorganization (Johnson et al. 2014). These results suggest that FGF21 induction may be an adaptive mechanism to protect the development and progression of pancreatitis. Given the protective role of FGF21 in pancreatitis, it will be of interest to study whether FGF21 exerts anti-cancer activity in the progression of pancreatic cancer.

\section{FGF21 and muscle disease}

Emerging evidence has suggested that FGF21 is expressed in skeletal muscle and that its expression is upregulated under muscle stress conditions, such as atrophy or myopathy (Izumiya et al. 2008, Tyynismaa et al. 2010). In transgenic mice expressing a mutant form of mitochondrial helicase Twinkle or muscle-specific cytochrome $c$ oxidase 10 (Cox10) knockout mice showing impairment of the mitochondrial respiratory chain and myopathy, skeletal muscle FGF21 expression was upregulated along with serum FGF21 levels (Tyynismaa et al. 2010). Moreover, serum FGF21 levels were increased in human subjects with mitochondrial respiratory chain deficiencies (Suomalainen et al. 2011), suggesting that FGF21 is a biomarker of muscle-manifesting mitochondrial respiratory chain disorders. Skeletal muscle-specific autophagy knockout mice showing muscle atrophy also exhibited increased muscular FGF21 induction, probably due to aggravated mitochondrial stress caused by autophagy deficiency (Kim et al. 2013a). Furthermore, it has been reported that several mitochondrial stressors, such as mitochondrial complex inhibitors, directly induce FGF21 expression via the eIF2 $\alpha$-ATF4 pathway (Kim et al. 2013a). Notably, all of these mice had reduced fat mass, probably due to increased energy expenditure and fatty acid catabolism induced by FGF21. Based on a report showing the beneficial effect of FGF21 on mitochondrial respiratory capacity (Chau et al. 2010), we speculate that FGF21 acts as an adaptive regulator counteracting muscle stress imposed by mitochondrial dysfunction or autophagy deficiency. Further studies are necessary to prove the protective role of FGF21 in the diseases associated with mitochondrial dysfunction.

\section{FGF21 and cardiovascular disease}

Accumulating evidence has suggested that FGF21 can modulate the development of coronary artery disease
(CAD) and atherosclerosis. It has been reported that FGF21 was increased in the serum of human subjects with CAD and carotid artery plaques, and increased FGF21 levels were associated with adverse lipid profiles in CAD subjects (Lin et al. 2010, Chow et al. 2013). A recent study has shown that the serum FGF21 level was also increased in atherosclerosis-prone apolipoprotein $\mathrm{E}$ knockout $\left(\right.$ Apoe $^{-1-}$ ) mice fed an atherogenic diet (Wu et al. 2014). FGF21 administration improved atherogenic diet-induced dyslipidemia and vascular atherosclerotic lesions in Apoe ${ }^{-1-}$ mice, probably by mitigating ER stress, a contributing factor in the pathogenesis of atherosclerosis (Wu et al. 2014). In addition, FGF21 treatment improved aggravated lipid profiles in atherosclerotic rats through its antioxidant effects (Zhu et al. 2014). The enhancement of cellular cholesterol efflux from macrophage-derived foam cells by FGF21 may also contribute to the improvement of atherosclerosis (Lin et al. 2014). Taken together, these findings suggest that FGF21 plays an adaptive and protective role in response to atherogenic stress, although further studies are needed to validate these findings.

Cardiokines, which are secreted from the heart in response to various cardiac stresses, play an important role in the maintenance of normal cardiac function through autocrine, paracrine, or endocrine mechanisms (Shimano et al. 2012). It has been reported that FGF21 expression was induced through a Sirt1-PPAR $\alpha$-dependent mechanism in the hearts of mice under various cardiac stress conditions such as isoproterenol/phenylephrine infusion, coronary artery ligation-induced myocardial infarction (ischemia), or transverse aortic constriction (Planavila et al. 2013). In addition, FGF21 expression was increased in the hearts of human subjects with dilated cardiomyopathy or advanced heart failure (Planavila et al. 2015). However, the source of FGF21 in these conditions is controversial, because another study showed FGF21 induction in the liver and adipose tissue but not in the ischemic myocardium of mice (Liu et al. 2013). Importantly, stress-induced cardiac hypertrophy was increased in $F g f 21^{-/-}$mice, while exogenous FGF21 administration ameliorated cardiac hypertrophy in these mice (Liu et al. 2013, Planavila et al. 2013). These results suggest that cardiac stressinduced FGF21 expression is a compensatory signal to protect against cardiac failure or cardiac dysfunction. Several mechanisms of improved stress-induced cardiac hypertrophy by FGF21 have been suggested. A role for the FGF receptor $1 / \beta$-klotho/protein kinase B (PKB/AKT) pathway in this process has been suggested in an in vivo study employing the strategy of siRNA administration to the anterior ventricular wall (Liu et al. 2013). In addition,

Published by Bioscientifica Ltd. 
i.m. injection of the adenovirus expressing FGF21 increased serum adiponectin levels and attenuated cardiac hypertrophy in mice with experimental myocardial infarction (Joki et al. 2015). Notably, FGF21-mediated cardiac protection was diminished in Adipoq $^{-/-}$mice, indicating that adiponectin mediates the beneficial effects of FGF21 on cardiac function. Enhancement of the antioxidant capacity via upregulation of antioxidant enzyme gene expression may contribute to the protective effects of FGF21 (Planavila et al. 2015). These results collectively suggest that FGF21 may be a pharmacological agent for treatment of myocardial injury.

\section{FGF21 and kidney disease}

It has been reported that serum FGF21 levels were increased in subjects with acute or chronic kidney diseases (Stein et al. 2009, Hindricks et al. 2014), and circulating FGF21 was elevated in proportion to the severity of kidney diseases (Lin et al. 2011). Increasingly, studies have suggested that FGF21 elicits protective effects against the progression of diabetic nephropathy, a leading cause of chronic renal failure (Kim et al. 2013c, Zhang et al. 2013a). FGF21 administration prevented renal lipid accumulation, oxidative stress, inflammation, and fibrosis in mice after treatment of excessive fatty acids or streptozotocin (Zhang et al. 2013a) and in leptin receptor-deficient $d b / d b$ mice with diabetic nephropathy (Kim et al. 2013c). Conversely, $\mathrm{Fg} f 21^{-1-}$ mice exhibited more aggravated lipotoxicity and renal damage compared to the control mice (Zhang et al. 2013a). These findings suggest that FGF21 induction is an adaptive mechanism to protect against renal injury in diabetic conditions and that FGF21 is a potential therapeutic agent for the treatment of diabetic nephropathy.

\section{The role of FGF21 in pharmacologic agent-induced metabolic benefits}

A growing body of evidence suggests that several pharmacologic agents that are currently available or are being developed for the treatment of metabolic diseases have a potential to induce FGF21. Here, we will review the functional role and molecular mechanisms of FGF21 induction by anti-diabetic drugs.

\section{Metformin and FGF21}

Metformin is a first-line agent for patients with T2D, according to the guidelines of the European Association for the Study of Diabetes and the American Diabetes Association. Metformin likely exerts its glucose-lowering effect through inhibition of glucose absorption in the intestine, suppression of gluconeogenesis in the liver, and enhancement of insulin actions in the liver, adipose tissue, or skeletal muscle (Foretz et al. 2014). The changes of composition or alterations of microbial metabolism in the gut microbiota are also involved in the beneficial metabolic effects of metformin (Cabreiro et al. 2013, Shin et al. 2014). The effect of metformin on suppression of gluconeogenesis has been reported to be dependent on AMPK, which functions as a conserved cellular energy sensor in an adaptive response to diverse energy stress conditions (Shaw et al. 2005, He et al. 2009). Metformininduced AMPK activation causes a decrease in the transcription of hepatic gluconeogenic enzyme genes, which depends on diverse factors such as CREB-regulated transcription coactivator 2 (He et al. 2009) and the small heterodimer partner (Kim et al. 2008). Metformin also improves hepatic lipid homeostasis by enhancing $\beta$-oxidation and suppressing lipogenesis in the liver via AMPK-mediated phosphorylation of acetyl CoA carboxylase (Fullerton et al. 2013). However, metformin is also able to suppress hepatic glucose production by altering the energy charge in an AMPK-independent manner without affecting gluconeogenic gene expression (Foretz et al. 2010). These effects are mediated by a reduced ATP level or an increased AMP/ATP ratio via partial inhibition of mitochondrial respiratory-chain complex I (Foretz et al. 2010, Miller et al. 2013).

Secretory proteins (or hormones) derived from major metabolic organs such as adipose tissue, muscle, and liver play a key role in the maintenance of energy homeostasis (Ouchi et al. 2011, Pedersen \& Febbraio 2012, Stefan \& Haring 2013). These secretory proteins may be involved in beneficial metabolic effects of metformin. Metformin treatment increased serum GLP1 levels in human subjects with or without T2D (Mannucci et al. 2004), as well as in obese diabetic mice (Kim et al. 2014b). In addition, metformin has been reported to induce FGF21 expression in hepatocytes through an AMPK-dependent pathway (Nygaard et al. 2012). We have observed that metformin causes FGF21 upregulation, which is dependent on the eIF2 $\alpha$-ATF 4 axis but not on AMPK (Kim et al. 2013d). Moreover, serum FGF21 levels in human subjects with T2D were shown to increase after 6 months of metformin treatment (Kim et al. 2013d). Hence, FGF21 induction by metformin may contribute to its metabolic effects. However, it has been also reported that the administration of metformin to human subjects with T2D for 1 week led

Published by Bioscientifica Ltd. 
to decreased serum FGF21 levels (Zhang et al. 2013b). Serum FGF21 levels in HIV-infected subjects treated with metformin for 12 months were not significantly different from those in the placebo group (Srinivasa et al. 2015). These discrepancies could be attributable to differences in patient selection, experimental analyses, or duration of metformin treatment. Since the numbers of human subjects studied were small, large-scale studies are needed to evaluate the role of FGF21 induction in the therapeutic effects of metformin.

\section{Glucagon, GLP1, and FGF21}

Glucagon secreted from pancreatic islet $\alpha$ cells is a well-known counterregulatory hormone that maintains glucose homeostasis by increasing gluconeogenesis and glycogenolysis in response to fasting or hypoglycemia. Hyperglucagonemia is observed in the early phase of insulin resistance/T2D and contributes to hyperglycemia by increasing the rate of hepatic glucose output and enhancing glycogen breakdown (Unger \& Cherrington 2012). Lipid metabolism and energy expenditure are also regulated by glucagon or glucagon agonism. Some studies have shown that glucagon decreased the levels of plasma TG and cholesterol in rats with or without hyperlipidemia (Eaton 1973). Glucagon also promotes lipolysis by activating hormone-sensitive lipase in white adipocytes (Slavin et al. 1994), enhances $\beta$ oxidation, and suppresses lipogenesis in hepatocytes (Prip-Buus et al. 1990). In addition, glucagon has been reported to increase energy expenditure in mice or human subjects, probably by stimulating oxygen consumption and heat production in BAT (Doi \& Kuroshima 1982, Tan et al. 2013). Thus, glucagon-induced beneficial effects on dyslipidemia and obesity make it an attractive therapeutic agent for treatment of metabolic disease, despite its potential ability to increase blood glucose level.

Intriguingly, glucagon and glucagon agonists have been reported to induce hepatic FGF21 gene expression, leading to the increase of serum FGF21 levels in mice and healthy human volunteers (Arafat et al. 2013, Habegger et al. 2013). The effects of glucagon agonism inducing body weight loss, hypocholesterolemia, and increased energy expenditure were lower in $\mathrm{Fg} f 21^{-1-}$ mice than in control mice (Habegger et al. 2013). Given that FGF21 reduces fat mass or serum cholesterol levels and enhances thermogenesis, FGF21 may act as a mediator of metabolic improvement by glucagon. A recent paper has shown that glucagon stimulates hepatic FGF21 secretion via PKA and Epac (exchange protein directly activated by cAMP)-dependent pathways without change of FGF21 mRNA expression (Cyphert et al. 2014), suggesting that glucagon increases FGF21 levels through post-translational mechanisms as well as transcriptional mechanisms.

GLP1, a proglucagon-derived peptide hormone, is secreted from L cells of the intestine in response to nutrients. GLP1 plays a key role in the control of glucose homeostasis by enhancing insulin release and suppressing glucagon secretion (Meier 2012). GLP1 also inhibits gastric emptying and induces satiety, which contributes to the suppression of food intake (Meier 2012). Five GLP1 receptor agonists (liraglutide, exenatide, lixisenatide, albiglutide and dulaglutide) are currently being used for the treatment of T2D. Intriguingly, GLP1 analogues also stimulate FGF21 expression, similar to glucagon or glucagon agonists. Treatment with liraglutide, a derivative of human GLP1 with a fatty acid chain, induced FGF21 gene expression in the liver but not in adipose tissue of $K K-A^{y}$ mice (Nonogaki et al. 2014); consequently, serum FGF21 levels were increased in liraglutide-treated $K K-A^{y}$ mice showing amelioration of hyperglycemia and obesity. Moreover, treatment with exendin-4 (the naturally occurring form of exenatide) for 10 weeks increased hepatic FGF21 gene expression in HFD-fed mice compared to control HFD-fed mice (Lee et al. 2014b). Dissimilar results regarding the effect of exendin-4 on FGF21 expression have also been reported. Hepatic FGF21 expression and serum FGF21 levels were decreased in HFD-fed mice treated with exendin- 4 for 4 weeks compared to saline treatment (Samson et al. 2011). Consistent with this result, the addition of exenatide reduced FGF21 levels in T2D subjects undergoing pioglitazone treatment (Samson et al. 2011). Furthermore, a decrease in hepatic FGF21 levels was correlated with reduction in hepatic TG content and liver weight in HFD-fed mice after exendin- 4 treatment, implying that reduction of FGF21 due to exendin-4 may be secondary to reduced lipid accumulation. Further studies are needed to evaluate the relationship between FGF21 induction and metabolic benefits by GLP1 analogues.

Combined glucagon/GLP1 dual agonists that retain the anti-hyperglycemic potential of GLP1 while avoiding the hyperglycemic effects of pure glucagon are being evaluated in clinical trials. The glucagon/GLP1 dual agonist is an attractive therapeutic agent as an anti-obesity drug as well as an anti-diabetic drug, due to the lipolytic and thermogenic properties of glucagon (Sadry \& Drucker 2013). Glucagon/GLP1 dual agonists also increased hepatic FGF21 expression and improved obesity-induced metabolic deterioration in mice, similar to glucagon or

Published by Bioscientifica Ltd. 
GLP1 agonists (Pocai et al. 2009). However, the role of FGF21 in glucagon/GLP1 dual agonism remains to be determined.

\section{PPAR $\gamma$ agonist (TZD) and FGF21}

TZD, a PPAR $\gamma$ agonist, is an anti-diabetic drug used for the treatment of T2D. TZD has been reported to enhance glucose uptake in adipose tissue or skeletal muscle and inhibit gluconeogenesis in the liver by reinforcing insulin action (Soccio et al. 2014). In addition to its role as an insulin sensitizer, TZD directly converts macrophage polarity from pro-inflammatory M1 to anti-inflammatory M2 type (Bouhlel et al. 2007) or indirectly via lipid partitioning (Prieur et al. 2011), probably leading to attenuation of obesity-induced adipose inflammation and insulin resistance. TZD may also elicit beneficial metabolic effects by regulating the levels or actions of hormones. Treatment with TZD caused an increase in serum adiponectin levels in obese mice and consequently improved obesity-induced glucose intolerance (Nawrocki et al. 2006). The effectiveness of TZD was diminished in

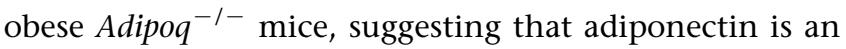
important contributor to TZD-mediated improvement of whole-body glucose metabolism (Nawrocki et al. 2006). In addition, TZD has been reported to increase FGF21 gene expression in adipose tissue, but not in the liver, through activation of PPAR $\gamma$ and, consequently, serum FGF21 levels are higher in TZD-treated mice compared to control mice (Muise et al. 2008). These results suggest a possible role of FGF21 in the anti-diabetic actions of TZD. In line with this assumption, obese $F g f 21^{-1-}$ mice were refractory to the metabolic effects of TZD (Dutchak et al. 2012). Notably, these effects of TZD are associated with the local action of FGF21 in adipose tissue but not with the systemic action. Adipose-derived FGF21 induction by TZD suppresses sumoylation of PPAR $\gamma$ and consequently enhances $\operatorname{PPAR} \gamma$ activity in adipose tissue, probably contributing to anti-diabetic effects of TZD (Dutchak et al. 2012). However, another paper reported that $F g f 21^{-1-}$ mice exhibited metabolic responses to TZD similar to those of Fof $21^{+/+}$mice (Adams et al. 2013a). Furthermore, PPAR $\gamma$ sumoylation in adipose tissue did not differ between the two groups after TZD treatment (Adams et al. 2013a). There is no clear explanation for these discrepancies, which might be attributable to the differences in knockout mouse strains or experimental procedures. Further studies are required to understand the relationship between FGF21 and PPAR $\gamma$ in TZD-induced pharmacologic actions. Given that both TZD and FGF21 induce browning of WAT
(Vernochet et al. 2009, Petrovic et al. 2010, Fisher et al. 2012), it will also be interesting to study the role of FGF21 in TZD-induced browning.

\section{Sirt1 activators and FGF21}

Sirt1, an NAD-dependent deacetylase, is an important regulator of cellular or whole-body energy metabolism through the modulation of acetylation/deacetylation of histones or non-histone proteins. Sirt1 gain- or loss-offunction studies in the whole-body or in specific organs have suggested that Sirt1 is a promising therapeutic target for the treatment of insulin resistance and T2D (Boutant \& Canto 2014). Pharmacologic studies have suggested that several Sirt1 activators have therapeutic efficacy in T2D associated with obesity. Resveratrol, a natural polyphenol product derived from grapes, is a well-known Sirt1 activator that improves metabolic profiles in obese mice (Baur et al. 2006, Lagouge et al. 2006) and human subjects with obesity or T2D (Timmers et al. 2011). SRT1720, a synthetic small molecule activator of Sirt1, improves insulin sensitivity and glucose tolerance (Milne et al. 2007). Sirt1-mediated regulation of glucose and lipid homeostasis may be elicited by various mechanisms, including an increase of PGC1 $\alpha$-mediated $\beta$ oxidation and mitochondrial biogenesis (Feige et al. 2008), suppression of sterol regulatory element-binding protein 1c-mediated fatty acid synthesis (Ponugoti et al. 2010), reduction of nuclear factor-kappa B-mediated macrophage inflammation (Schug et al. 2010), or enhancement of PPAR $\gamma$-mediated browning (Qiang et al. 2012). In addition, Sirt1-mediated changes in the levels of certain hormones may contribute to its beneficial metabolic action. Sirt1 induces adiponectin gene expression through deacetylation of forkhead box O1 (Qiao \& Shao 2006), which may help improve glucose tolerance and insulin sensitivity. Additionally, it has been reported that Sirt1 increases insulin secretion through the suppression of transcription of uncoupling protein 2 (Bordone et al. 2006). Resveratrol has been also reported to enhance insulin release from pancreatic $\beta$ cells (Vetterli et al. 2011). A recent paper reported that Sirt1 or its activators (resveratrol and SRT1720) induced FGF21 gene expression in the liver of mice and that liver-specific Sirt1 knockout $\left(\right.$ Sirt $\left.1^{\text {Ahep }}\right)$ mice had a reduced hepatic expression and serum level of FGF21 compared to control mice in response to fasting (Li et al. 2014). Importantly, Sirt $1^{\text {shep }}$ mice exhibited reduced ketogenesis and increased hepatic lipid accumulation in fasting conditions; this was rescued by adenovirus-mediated hepatic FGF21 overexpression

Published by Bioscientifica Ltd. 
(Li et al. 2014). These results suggest that Sirt1-mediated FGF21 induction plays an important role in the adaptive metabolic response to fasting. Furthermore, Sirt1 may participate in GLP1 receptor agonist-induced FGF21 expression in hepatocytes (Lee et al. 2014b). Further studies will be necessary to elucidate the role of FGF21 in the metabolic improvement by Sirt1 activators.

\section{Other pharmacological compounds and FGF21}

A growing body of evidence suggests that other therapeutic reagents influence FGF21 gene expression. Lipoic acid, also known as thioctic acid, is an octanoic acidderived organosulfur compound that is naturally synthesized in small amounts in the body (Shay et al. 2009). Lipoic acid plays an important role in the maintenance of mitochondrial respiratory capacity as a cofactor that covalently binds to mitochondrial complex enzymes (Shay et al. 2009). Numerous studies have suggested that lipoic acid supplements improved glucose intolerance and insulin sensitivity in mice and human subjects (Jacob et al. 1999). In Germany, lipoic acid is medically approved for the treatment of adult-onset T2D and diabetic complications such as diabetic neuropathy. Lipoic acid has been reported to regulate glucose and lipid metabolism by modulating the activity of Sirt1 or AMPK (Park et al. 2008, Yang et al. 2014). Importantly, lipoic acid has been also reported to induce FGF21 expression in hepatocytes and in the livers of mice, probably via upregulation of CREBH (Bae et al. 2014). However, a biological role of FGF21 in lipoic acid-induced metabolic improvement remains to be determined. Acarbose, an $\alpha$-glycoside hydrolase inhibitor that is being used as an anti-diabetic drug, has been reported to increase serum FGF21 levels in aged mice (Harrison et al. 2014). Given the effects of acarbose on the enhancement of the life-span and improvement of metabolic derangement (Harrison et al. 2014), these findings suggest that acarbose may elicit its metabolic actions through FGF21. This issue awaits further investigation.

\section{Conclusions}

Numerous studies have suggested that FGF21 is a promising therapeutic agent for the treatment of obesityrelated insulin resistance due to its multiple actions on diverse metabolic target organs. In addition to the metabolic effects of FGF21, we discussed the importance of FGF21 induction in several disease conditions such as muscle atrophy, liver injury, cardiovascular disease, and renal injury. FGF21 may also play a protective role against glutamate-induced neuronal excitotoxicity (Leng et al. 2015) or chemical-induced testicular injury (Jiang et al. 2013). Chronic FGF21 overexpression has been reported to extend the life-span in mice, probably through a mechanism involving suppression of the GH/insulin-like growth factor 1 signaling pathway (Zhang et al. 2012). Despite diverse beneficial effects of FGF21, it may have side effects such as growth retardation (Inagaki et al. 2008), bone loss (Wei et al. 2012), and female infertility (Owen et al. 2013). Further studies are needed to evaluate the legitimate therapeutic role of FGF21 or its mimetics in several diseases, which will provide new strategies to develop novel agents without adverse effects. In addition, further work on the elucidation of uncharacterized downstream effectors of FGF21 in specific organs will help develop promising drug targets capable of mimicking the beneficial effects of FGF21.

\section{Declaration of interest}

The authors declare that there is no conflict of interest that could be perceived as prejudicing the impartiality of this review.

\section{Funding}

This work was supported by the Basic Science Research Program through the National Research Foundation of Korea funded by the Ministry of Education (2013R1A6A3A04065825 to K H K) and by the Global Research Laboratory Grant of the National Research Foundation of Korea (K21004000003-10A0500-00310 to M-S L). M-S L is the recipient of the Ulsan National Institute of Science and Technology Research Fund (2014M3A9D8034459).

\section{References}

Ables GP, Perrone CE, Orentreich D \& Orentreich N 2012 Methioninerestricted $\mathrm{C} 57 \mathrm{BL} / 6 \mathrm{~J}$ mice are resistant to diet-induced obesity and insulin resistance but have low bone density. PLoS ONE 7 e51357. (doi:10.1371/journal.pone.0051357)

Adams AC, Astapova I, Fisher FM, Badman MK, Kurgansky KE, Flier JS, Hollenberg AN \& Maratos-Flier E 2010 Thyroid hormone regulates hepatic expression of fibroblast growth factor 21 in a PPAR $\alpha$-dependent manner. Journal of Biological Chemistry 285 14078-14082. (doi:10.1074/ jbc.C110.107375)

Adams AC, Cheng CC, Coskun T \& Kharitonenkov A 2012 FGF21 requires $\beta$ klotho to act in vivo. PLoS ONE 7 e49977. (doi:10.1371/journal.pone. 0049977)

Adams AC, Coskun T, Cheng CC, O'Farrell LS, Dubois SL \& Kharitonenkov A 2013a Fibroblast growth factor 21 is not required for the antidiabetic actions of the thiazolidinediones. Molecular Metabolism 2 205-214. (doi:10.1016/j.molmet.2013.05.005)

Adams AC, Halstead CA, Hansen BC, Irizarry AR, Martin JA, Myers SR, Reynolds VL, Smith HW, Wroblewski VJ \& Kharitonenkov A $2013 b$ LY2405319, an engineered FGF21 variant, improves the metabolic status of diabetic monkeys. PLOS ONE $\mathbf{8}$ e65763. (doi:10.1371/journal. pone.0065763)

Published by Bioscientifica Ltd. 
Arafat AM, Kaczmarek P, Skrzypski M, Pruszynska-Oszmalek E, Kolodziejski P, Szczepankiewicz D, Sassek M, Wojciechowicz T, Wiedenmann B, Pfeiffer AF et al. 2013 Glucagon increases circulating fibroblast growth factor 21 independently of endogenous insulin levels: a novel mechanism of glucagon-stimulated lipolysis? Diabetologia 56 588-597. (doi:10.1007/s00125-012-2803-y)

Assini JM, Mulvihill EE, Burke AC, Sutherland BG, Telford DE, Chhoker SS, Sawyez CG, Drangova M, Adams AC, Kharitonenkov A et al. 2015 Naringenin prevents obesity, hepatic steatosis and glucose intolerance in male mice independent of fibroblast growth factor 21 . Endocrinology 156 2087-2102. (doi:10.1210/en.2014-2003)

Badman MK, Pissios P, Kennedy AR, Koukos G, Flier JS \& Maratos-Flier E 2007 Hepatic fibroblast growth factor 21 is regulated by PPAR $\alpha$ and is a key mediator of hepatic lipid metabolism in ketotic states. Cell Metabolism 5 426-437. (doi:10.1016/j.cmet.2007.05.002)

Badman MK, Koester A, Flier JS, Kharitonenkov A \& Maratos-Flier E 2009 Fibroblast growth factor 21-deficient mice demonstrate impaired adaptation to ketosis. Endocrinology 150 4931-4940. (doi:10.1210/en. 2009-0532)

Bae KH, Min AK, Kim JG, Lee IK \& Park KG 2014 Alpha lipoic acid induces hepatic fibroblast growth factor 21 expression via up-regulation of CREBH. Biochemical and Biophysical Research Communications 455 212-217. (doi:10.1016/j.bbrc.2014.10.147)

Baur JA, Pearson KJ, Price NL, Jamieson HA, Lerin C, Kalra A, Prabhu VV, Allard JS, Lopez-Lluch G, Lewis K et al. 2006 Resveratrol improves health and survival of mice on a high-calorie diet. Nature 444 337-342. (doi:10.1038/nature05354)

Bordone L, Motta MC, Picard F, Robinson A, Jhala US, Apfeld J, McDonagh T, Lemieux M, McBurney M, Szilvasi A et al. 2006 Sirt1 regulates insulin secretion by repressing UCP2 in pancreatic $\beta$ cells PLoS Biology 4 e31. (doi:10.1371/journal.pbio.0040031)

Bouhlel MA, Derudas B, Rigamonti E, Dievart R, Brozek J, Haulon S, Zawadzki C, Jude B, Torpier G, Marx N et al. 2007 PPAR $\gamma$ activation primes human monocytes into alternative M2 macrophages with anti-inflammatory properties. Cell Metabolism 6 137-143. (doi:10.1016/ j.cmet.2007.06.010)

Boutant M \& Canto C 2014 SIRT1 metabolic actions: integrating recent advances from mouse models. Molecular Metabolism 3 5-18. (doi:10.1016/j.molmet.2013.10.006)

Cabreiro F, Au C, Leung KY, Vergara-Irigaray N, Cocheme HM, Noori T, Weinkove D, Schuster E, Greene ND \& Gems D 2013 Metformin retards aging in C. elegans by altering microbial folate and methionine metabolism. Cell 153 228-239. (doi:10.1016/j.cell.2013.02.035)

Chau MD, Gao J, Yang Q, Wu Z \& Gromada J 2010 Fibroblast growth factor 21 regulates energy metabolism by activating the AMPK-SIRT1-PGC-1 $\alpha$ pathway. PNAS 107 12553-12558. (doi:10.1073/pnas.1006962107)

Chavez AO, Molina-Carrion M, Abdul-Ghani MA, Folli F, Defronzo RA \& Tripathy D 2009 Circulating fibroblast growth factor-21 is elevated in impaired glucose tolerance and type 2 diabetes and correlates with muscle and hepatic insulin resistance. Diabetes Care 32 1542-1546. (doi:10.2337/dc09-0684)

Chen W, Hoo RL, Konishi M, Itoh N, Lee PC, Ye HY, Lam KS \& Xu A 2011 Growth hormone induces hepatic production of fibroblast growth factor 21 through a mechanism dependent on lipolysis in adipocytes. Journal of Biological Chemistry 286 34559-34566. (doi:10.1074/jbc. M111.285965)

Cheng X, Vispute SG, Liu J, Cheng C, Kharitonenkov A \& Klaassen CD 2014 Fibroblast growth factor (Fgf) 21 is a novel target gene of the aryl hydrocarbon receptor (AhR). Toxicology and Applied Pharmacology 278 65-71. (doi:10.1016/j.taap.2014.04.013)

Chow WS, Xu A, Woo YC, Tso AW, Cheung SC, Fong CH, Tse HF, Chau MT, Cheung BM \& Lam KS 2013 Serum fibroblast growth factor-21 levels are associated with carotid atherosclerosis independent of established cardiovascular risk factors. Arteriosclerosis, Thrombosis, and Vascular Biology 33 2454-2459. (doi:10.1161/ATVBAHA.113.301599)
Coskun T, Bina HA, Schneider MA, Dunbar JD, Hu CC, Chen Y, Moller DE \& Kharitonenkov A 2008 Fibroblast growth factor 21 corrects obesity in mice. Endocrinology 149 6018-6027. (doi:10.1210/en.2008-0816)

Cuevas-Ramos D, Almeda-Valdes P, Meza-Arana CE, Brito-Cordova G, Gomez-Perez FJ, Mehta R, Oseguera-Moguel J \& Aguilar-Salinas CA 2012 Exercise increases serum fibroblast growth factor 21 (FGF21) levels. PLOS ONE 7 e38022. (doi:10.1371/journal.pone.0038022)

Cyphert HA, Alonge KM, Ippagunta SM \& Hillgartner FB 2014 Glucagon stimulates hepatic FGF21 secretion through a PKA- and EPACdependent posttranscriptional mechanism. PLOS ONE 9 e94996. (doi:10.1371/journal.pone.0094996)

De Sousa-Coelho AL, Relat J, Hondares E, Perez-Marti A, Ribas F, Villarroya F, Marrero PF \& Haro D 2013 FGF21 mediates the lipid metabolism response to amino acid starvation. Journal of Lipid Research 54 1786-1797. (doi:10.1194/jlr.M033415)

Ding X, Boney-Montoya J, Owen BM, Bookout AL, Coate KC, Mangelsdorf DJ \& Kliewer SA 2012 ßKlotho is required for fibroblast growth factor 21 effects on growth and metabolism. Cell Metabolism 16 387-393. (doi:10.1016/j.cmet.2012.08.002)

Doi K \& Kuroshima A 1982 Thermogenic response to glucagon in coldacclimated mice. Japanese Journal of Physiology 32 377-385. (doi:10.2170/jjphysiol.32.377)

Domouzoglou EM, Fisher FM, Astapova I, Fox EC, Kharitonenkov A, Flier JS, Hollenberg AN \& Maratos-Flier E 2014 Fibroblast growth factor 21 and thyroid hormone show mutual regulatory dependency but have independent actions in vivo. Endocrinology 155 2031-2040. (doi:10.1210/en.2013-1902)

Dushay J, Chui PC, Gopalakrishnan GS, Varela-Rey M, Crawley M, Fisher FM, Badman MK, Martinez-Chantar ML \& Maratos-Flier E 2010 Increased fibroblast growth factor 21 in obesity and nonalcoholic fatty liver disease. Gastroenterology 139 456-463. (doi:10.1053/j.gastro.2010. 04.054)

Dushay JR, Toschi E, Mitten EK, Fisher FM, Herman MA \& Maratos-Flier E 2015 Fructose ingestion acutely stimulates circulating FGF21 levels in humans. Molecular Metabolism 4 51-57. (doi:10.1016/j.molmet.2014. 09.008)

Dutchak PA, Katafuchi T, Bookout AL, Choi JH, Yu RT, Mangelsdorf DJ \& Kliewer SA 2012 Fibroblast growth factor-21 regulates PPAR $\gamma$ activity and the antidiabetic actions of thiazolidinediones. Cell 148 556-567. (doi:10.1016/j.cell.2011.11.062)

Eaton RP 1973 Hypolipemic action of glucagon in experimental endogenous lipemia in the rat. Journal of Lipid Research 14 312-318.

Emanuelli B, Vienberg SG, Smyth G, Cheng C, Stanford KI, Arumugam M, Michael MD, Adams AC, Kharitonenkov A \& Kahn CR 2014 Interplay between FGF21 and insulin action in the liver regulates metabolism. Journal of Clinical Investigation 124 515-527. (doi:10.1172/ JCI67353)

Feige JN, Lagouge M, Canto C, Strehle A, Houten SM, Milne JC, Lambert PD, Mataki C, Elliott PJ \& Auwerx J 2008 Specific SIRT1 activation mimics low energy levels and protects against diet-induced metabolic disorders by enhancing fat oxidation. Cell Metabolism 8 347-358. (doi:10.1016/j. cmet.2008.08.017)

Fisher FM, Chui PC, Antonellis PJ, Bina HA, Kharitonenkov A, Flier JS \& Maratos-Flier E 2010 Obesity is a fibroblast growth factor 21 (FGF21)resistant state. Diabetes 59 2781-2789. (doi:10.2337/db10-0193)

Fisher FM, Kleiner S, Douris N, Fox EC, Mepani RJ, Verdeguer F, Wu J, Kharitonenkov A, Flier JS, Maratos-Flier E et al. 2012 FGF21 regulates PGC- $1 \alpha$ and browning of white adipose tissues in adaptive thermogenesis. Genes and Development 26 271-281. (doi:10.1101/gad. 177857.111)

Fisher FM, Chui PC, Nasser IA, Popov Y, Cunniff JC, Lundasen T, Kharitonenkov A, Schuppan D, Flier JS \& Maratos-Flier E 2014 Fibroblast growth factor 21 limits lipotoxicity by promoting hepatic fatty acid activation in mice on methionine and choline-deficient diets. Gastroenterology 147 1073-1083 (e1076). (doi:10.1053/j.gastro.2014. 07.044) 
Foltz IN, Hu S, King C, Wu X, Yang C, Wang W, Weiszmann J, Stevens J, Chen JS, Nuanmanee $\mathrm{N}$ et al. 2012 Treating diabetes and obesity with an FGF21-mimetic antibody activating the $\beta$ Klotho/FGFR1c receptor complex. Science Translational Medicine 4 162ra153. (doi:10.1126/ scitranslmed.3004690)

Foretz M, Hebrard S, Leclerc J, Zarrinpashneh E, Soty M, Mithieux G, Sakamoto K, Andreelli F \& Viollet B 2010 Metformin inhibits hepatic gluconeogenesis in mice independently of the LKB1/AMPK pathway via a decrease in hepatic energy state. Journal of Clinical Investigation 120 2355-2369. (doi:10.1172/JCI40671)

Foretz M, Guigas B, Bertrand L, Pollak M \& Viollet B 2014 Metformin: from mechanisms of action to therapies. Cell Metabolism 20 953-966. (doi:10.1016/j.cmet.2014.09.018)

Fullerton MD, Galic S, Marcinko K, Sikkema S, Pulinilkunnil T, Chen ZP, O'Neill HM, Ford RJ, Palanivel R, O'Brien M et al. 2013 Single phosphorylation sites in Acc1 and Acc2 regulate lipid homeostasis and the insulin-sensitizing effects of metformin. Nature Medicine 19 1649-1654. (doi:10.1038/nm.3372)

Gaich G, Chien JY, Fu H, Glass LC, Deeg MA, Holland WL, Kharitonenkov A, Bumol T, Schilske HK \& Moller DE 2013 The effects of LY2405319, an FGF21 analog, in obese human subjects with type 2 diabetes. Cell Metabolism 18 333-340. (doi:10.1016/j.cmet.2013.08.005)

Galman C, Lundasen T, Kharitonenkov A, Bina HA, Eriksson M, Hafstrom I, Dahlin M, Amark P, Angelin B \& Rudling M 2008 The circulating metabolic regulator FGF21 is induced by prolonged fasting and PPAR $\alpha$ activation in man. Cell Metabolism 8 169-174. (doi:10.1016/j.cmet. 2008.06.014)

Habegger KM, Stemmer K, Cheng C, Muller TD, Heppner KM, Ottaway N, Holland J, Hembree JL, Smiley D, Gelfanov V et al. 2013 Fibroblast growth factor 21 mediates specific glucagon actions. Diabetes $\mathbf{6 2}$ 1453-1463. (doi:10.2337/db12-1116)

Harms M \& Seale P 2013 Brown and beige fat: development, function and therapeutic potential. Nature Medicine 19 1252-1263. (doi:10.1038/nm. 3361)

Harrison DE, Strong R, Allison DB, Ames BN, Astle CM, Atamna H, Fernandez E, Flurkey K, Javors MA, Nadon NL et al. 2014 Acarbose, 17 - $\alpha$-estradiol, and nordihydroguaiaretic acid extend mouse lifespan preferentially in males. Aging Cell 13 273-282. (doi:10.1111/acel. 12170)

Hasek BE, Stewart LK, Henagan TM, Boudreau A, Lenard NR, Black C, Shin J, Huypens P, Malloy VL, Plaisance EP et al. 2010 Dietary methionine restriction enhances metabolic flexibility and increases uncoupled respiration in both fed and fasted states. American Journal of Physiology. Regulatory, Integrative and Comparative Physiology 299 R728-R739. (doi:10.1152/ajpregu.00837.2009)

He L, Sabet A, Djedjos S, Miller R, Sun X, Hussain MA, Radovick S \& Wondisford FE 2009 Metformin and insulin suppress hepatic gluconeogenesis through phosphorylation of CREB binding protein. Cell 137 635-646. (doi:10.1016/j.cell.2009.03.016)

Hindricks J, Ebert T, Bachmann A, Kralisch S, Lossner U, Kratzsch J, Stolzenburg JU, Dietel A, Beige J, Anders M et al. 2014 Serum levels of fibroblast growth factor- 21 are increased in chronic and acute renal dysfunction. Clinical Endocrinology 80 918-924. (doi:10.1111/cen. 12380)

Holland WL, Adams AC, Brozinick JT, Bui HH, Miyauchi Y, Kusminski CM, Bauer SM, Wade M, Singhal E, Cheng CC et al. 2013 An FGF21adiponectin-ceramide axis controls energy expenditure and insulin action in mice. Cell Metabolism 17 790-797. (doi:10.1016/j.cmet.2013. 03.019)

Hondares E, Iglesias R, Giralt A, Gonzalez FJ, Giralt M, Mampel T \& Villarroya F 2011 Thermogenic activation induces FGF21 expression and release in brown adipose tissue. Journal of Biological Chemistry $\mathbf{2 8 6}$ 12983-12990. (doi:10.1074/jbc.M110.215889)

Huang X, Yu C, Jin C, Yang C, Xie R, Cao D, Wang F \& McKeehan WL 2006 Forced expression of hepatocyte-specific fibroblast growth factor 21 delays initiation of chemically induced hepatocarcinogenesis. Molecular Carcinogenesis 45 934-942. (doi:10.1002/mc.20241)

Iizuka K, Takeda J \& Horikawa Y 2009 Glucose induces FGF21 mRNA expression through ChREBP activation in rat hepatocytes. FEBS Letters 583 2882-2886. (doi:10.1016/j.febslet.2009.07.053)

Inagaki T, Dutchak P, Zhao G, Ding X, Gautron L, Parameswara V, Li Y, Goetz R, Mohammadi M, Esser V et al. 2007 Endocrine regulation of the fasting response by PPAR $\alpha$-mediated induction of fibroblast growth factor 21. Cell Metabolism 5 415-425. (doi:10.1016/j.cmet.2007.05.003)

Inagaki T, Lin VY, Goetz R, Mohammadi M, Mangelsdorf DJ \& Kliewer SA 2008 Inhibition of growth hormone signaling by the fasting-induced hormone FGF21. Cell Metabolism 8 77-83. (doi:10.1016/j.cmet.2008. 05.006)

Izumiya Y, Bina HA, Ouchi N, Akasaki Y, Kharitonenkov A \& Walsh K 2008 FGF21 is an Akt-regulated myokine. FEBS Letters $\mathbf{5 8 2} 3805-3810$. (doi:10.1016/j.febslet.2008.10.021)

Jacob S, Rett K, Henriksen EJ \& Haring HU 1999 Thioctic acid - effects on insulin sensitivity and glucose-metabolism. BioFactors 10 169-174. (doi:10.1002/biof.5520100212)

Jiang X, Zhang C, Xin Y, Huang Z, Tan Y, Huang Y, Wang Y, Feng W, Li X, Li W et al. 2013 Protective effect of FGF21 on type 1 diabetes-induced testicular apoptotic cell death probably via both mitochondrial- and endoplasmic reticulum stress-dependent pathways in the mouse model. Toxicology Letters 219 65-76. (doi:10.1016/j.toxlet.2013.02.022)

Jiang S, Yan C, Fang QC, Shao ML, Zhang YL, Liu Y, Deng YP, Shan B, Liu JQ, Li HT et al. 2014 Fibroblast growth factor 21 is regulated by the IRE1 $\alpha-$ XBP1 branch of the unfolded protein response and counteracts endoplasmic reticulum stress-induced hepatic steatosis. Journal of Biological Chemistry 289 29751-29765. (doi:10.1074/jbc.M114.565960)

Johnson CL, Weston JY, Chadi SA, Fazio EN, Huff MW, Kharitonenkov A, Koester A \& Pin CL 2009 Fibroblast growth factor 21 reduces the severity of cerulein-induced pancreatitis in mice. Gastroenterology 137 1795-1804. (doi:10.1053/j.gastro.2009.07.064)

Johnson CL, Mehmood R, Laing SW, Stepniak CV, Kharitonenkov A \& Pin CL 2014 Silencing of the fibroblast growth factor 21 gene is an underlying cause of acinar cell injury in mice lacking MIST1. American Journal of Physiology. Endocrinology and Metabolism 306 E916-E928. (doi:10.1152/ajpendo.00559.2013)

Joki Y, Ohashi K, Yuasa D, Shibata R, Ito M, Matsuo K, Kambara T, Uemura Y, Hayakawa S, Hiramatsu-Ito M et al. 2015 FGF21 attenuates pathological myocardial remodeling following myocardial infarction through the adiponectin-dependent mechanism. Biochemical and Biophysical Research Communications 459 124-130. (doi:10.1016/j.bbrc.2015.02.081)

Kharitonenkov A, Shiyanova TL, Koester A, Ford AM, Micanovic R, Galbreath EJ, Sandusky GE, Hammond LJ, Moyers JS, Owens RA et al. 2005 FGF-21 as a novel metabolic regulator. Journal of Clinical Investigation 115 1627-1635. (doi:10.1172/JCI23606)

Kim KH \& Lee MS 2014 FGF21 as a stress hormone: the roles of FGF21 in stress adaptation and the treatment of metabolic diseases. Diabetes \& Metabolism Journal 38 245-251. (doi:10.4093/dmj.2014.38.4.245)

Kim YD, Park KG, Lee YS, Park YY, Kim DK, Nedumaran B, Jang WG, Cho WJ, Ha J, Lee IK et al. 2008 Metformin inhibits hepatic gluconeogenesis through AMP-activated protein kinase-dependent regulation of the orphan nuclear receptor SHP. Diabetes 57 306-314. (doi:10.2337/db07-0381)

Kim KH, Jeong YT, Oh H, Kim SH, Cho JM, Kim YN, Kim SS, Kim do H, Hur KY, Kim HK et al. 2013a Autophagy deficiency leads to protection from obesity and insulin resistance by inducing Fgf21 as a mitokine. Nature Medicine 19 83-92. (doi:10.1038/nm.3014)

Kim KH, Kim SH, Min YK, Yang HM, Lee JB \& Lee MS 2013b Acute exercise induces FGF21 expression in mice and in healthy humans. PLOS ONE 8 e63517. (doi:10.1371/journal.pone.0063517)

Kim HW, Lee JE, Cha JJ, Hyun YY, Kim JE, Lee MH, Song HK, Nam DH, Han JY, Han SY et al. 2013c Fibroblast growth factor 21 improves insulin resistance and ameliorates renal injury in $d b / d b$ mice. Endocrinology 154 3366-3376. (doi:10.1210/en.2012-2276) 
Kim KH, Jeong YT, Kim SH, Jung HS, Park KS, Lee HY \& Lee MS 2013d Metformin-induced inhibition of the mitochondrial respiratory chain increases FGF21 expression via ATF4 activation. Biochemical and Biophysical Research Communications 440 76-81. (doi:10.1016/j.bbrc. 2013.09.026)

Kim H, Mendez R, Zheng Z, Chang L, Cai J, Zhang R \& Zhang K 2014a Liverenriched transcription factor CREBH interacts with peroxisome proliferator-activated receptor $\alpha$ to regulate metabolic hormone FGF21. Endocrinology 155 769-782. (doi:10.1210/en.2013-1490)

Kim MH, Jee JH, Park S, Lee MS, Kim KW \& Lee MK 2014b Metformin enhances glucagon-like peptide 1 via cooperation between insulin and Wnt signaling. Journal of Endocrinology 220 117-128. (doi:10.1530/ JOE-13-0381)

Kim SH, Kim KH, Kim HK, Kim MJ, Back SH, Konishi M, Itoh N \& Lee MS 2015 Fibroblast growth factor 21 participates in adaptation to endoplasmic reticulum stress and attenuates obesity-induced hepatic metabolic stress. Diabetologia 58 809-818. (doi:10.1007/s00125-0143475-6)

Kong LJ, Feng W, Wright M, Chen Y, Dallas-yang Q, Zhou YP \& Berger JP 2013 FGF21 suppresses hepatic glucose production through the activation of atypical protein kinase $\mathrm{C} / \lambda$. European Journal of Pharmacology 702 302-308. (doi:10.1016/j.ejphar.2012.11.065)

Kubicky RA, Wu S, Kharitonenkov A \& De Luca F 2012 Role of fibroblast growth factor 21 (FGF21) in undernutrition-related attenuation of growth in mice. Endocrinology 153 2287-2295. (doi:10.1210/en. 2011-1909)

Laeger T, Henagan TM, Albarado DC, Redman LM, Bray GA, Noland RC, Munzberg H, Hutson SM, Gettys TW, Schwartz MW et al. 2014 FGF21 is an endocrine signal of protein restriction. Journal of Clinical Investigation 124 3913-3922. (doi:10.1172/JCI74915)

Lagouge M, Argmann C, Gerhart-Hines Z, Meziane H, Lerin C, Daussin F, Messadeq N, Milne J, Lambert P, Elliott P et al. 2006 Resveratrol improves mitochondrial function and protects against metabolic disease by activating SIRT1 and PGC-1 $\alpha$. Cell 127 1109-1122. (doi:10.1016/j.cell.2006.11.013)

Lee JH, Giannikopoulos P, Duncan SA, Wang J, Johansen CT, Brown JD, Plutzky J, Hegele RA, Glimcher LH \& Lee AH 2011 The transcription factor cyclic AMP-responsive element-binding protein $\mathrm{H}$ regulates triglyceride metabolism. Nature Medicine 17 812-815. (doi:10.1038/ $\mathrm{nm} .2347)$

Lee P, Linderman JD, Smith S, Brychta RJ, Wang J, Idelson C, Perron RM, Werner CD, Phan GQ, Kammula US et al. 2014a Irisin and FGF21 are cold-induced endocrine activators of brown fat function in humans. Cell Metabolism 19 302-309. (doi:10.1016/j.cmet.2013.12.017)

Lee J, Hong SW, Park SE, Rhee EJ, Park CY, Oh KW, Park SW \& Lee WY $2014 b$ Exendin-4 regulates lipid metabolism and fibroblast growth factor 21 in hepatic steatosis. Metabolism 63 1041-1048. (doi:10.1016/ j.metabol.2014.04.011)

Lees EK, Krol E, Grant L, Shearer K, Wyse C, Moncur E, Bykowska AS, Mody N, Gettys TW \& Delibegovic M 2014 Methionine restriction restores a younger metabolic phenotype in adult mice with alterations in fibroblast growth factor 21. Aging Cell 13 817-827. (doi:10.1111/acel. 12238)

Leng Y, Wang Z, Tsai LK, Leeds P, Fessler EB, Wang J \& Chuang DM 2015 FGF-21, a novel metabolic regulator, has a robust neuroprotective role and is markedly elevated in neurons by mood stabilizers. Molecular Psychiatry 20 215-223. (doi:10.1038/mp.2013.192)

Li H, Fang Q, Gao F, Fan J, Zhou J, Wang X, Zhang H, Pan X, Bao Y, Xiang K et al. 2010 Fibroblast growth factor 21 levels are increased in nonalcoholic fatty liver disease patients and are correlated with hepatic triglyceride. Journal of Hepatology 53 934-940. (doi:10.1016/j.jhep. 2010.05.018)

Li Y, Wong K, Giles A, Jiang J, Lee JW, Adams AC, Kharitonenkov A, Yang Q, Gao B, Guarente L et al. 2014 Hepatic SIRT1 attenuates hepatic steatosis and controls energy balance in mice by inducing fibroblast growth factor 21. Gastroenterology 146 539-549.e7. (doi:10.1053/ j.gastro.2013.10.059)

Liang Q, Zhong L, Zhang J, Wang Y, Bornstein SR, Triggle CR, Ding H, Lam KS \& Xu A 2014 FGF21 maintains glucose homeostasis by mediating the cross talk between liver and brain during prolonged fasting. Diabetes 63 4064-4075. (doi:10.2337/db14-0541)

Lin Z, Wu Z, Yin X, Liu Y, Yan X, Lin S, Xiao J, Wang X, Feng W \& Li X 2010 Serum levels of FGF-21 are increased in coronary heart disease patients and are independently associated with adverse lipid profile. PLOS ONE 5 e15534. (doi:10.1371/journal.pone.0015534)

Lin Z, Zhou Z, Liu Y, Gong Q, Yan X, Xiao J, Wang X, Lin S, Feng W \& Li X 2011 Circulating FGF21 levels are progressively increased from the early to end stages of chronic kidney diseases and are associated with renal function in Chinese. PLOS ONE 6 e18398. (doi:10.1371/journal.pone. 0018398)

Lin Z, Tian H, Lam KS, Lin S, Hoo RC, Konishi M, Itoh N, Wang Y, Bornstein SR, Xu A et al. 2013 Adiponectin mediates the metabolic effects of FGF21 on glucose homeostasis and insulin sensitivity in mice. Cell Metabolism 17 779-789. (doi:10.1016/j.cmet.2013.04.005)

Lin XL, He XL, Zeng JF, Zhang H, Zhao Y, Tan JK \& Wang Z 2014 FGF21 increases cholesterol efflux by upregulating ABCA1 through the ERK1/2-PPAR $\gamma$-LXR $\alpha$ pathway in THP1 macrophage-derived foam cells. DNA and Cell Biology 33 514-521. (doi:10.1089/dna.2013.2290)

Lips MA, de Groot GH, Berends FJ, Wiezer R, van Wagensveld BA, Swank DJ, Luijten A, van Dijk KW, Pijl H, Jansen PL et al. 2014 Calorie restriction and Roux-en-Y gastric bypass have opposing effects on circulating FGF21 in morbidly obese subjects. Clinical Endocrinology 81 862-870. (doi:10.1111/cen.12496)

Liu SQ, Roberts D, Kharitonenkov A, Zhang B, Hanson SM, Li YC, Zhang LQ \& Wu YH 2013 Endocrine protection of ischemic myocardium by FGF21 from the liver and adipose tissue. Scientific Reports 32767. (doi:10.1038/srep02767)

Loyd C, Magrisso IJ, Haas M, Balusu S, Itoh N, Sandoval DA, Obici S, PerezTilve D \& Habegger KM 2014 Fibroblast growth factor 21 mediates the beneficial effects of exercise on diet-induced glucose intolerance. Diabetes 63(Supplement 1) A1-A102.

Mai K, Andres J, Biedasek K, Weicht J, Bobbert T, Sabath M, Meinus S, Reinecke F, Mohlig M, Weickert MO et al. 2009 Free fatty acids link metabolism and regulation of the insulin-sensitizing fibroblast growth factor-21. Diabetes 58 1532-1538. (doi:10.2337/db08-1775)

Mannucci E, Tesi F, Bardini G, Ognibene A, Petracca MG, Ciani S, Pezzatini A, Brogi M, Dicembrini I, Cremasco F et al. 2004 Effects of metformin on glucagon-like peptide-1 levels in obese patients with and without type 2 diabetes. Diabetes, Nutrition \& Metabolism 17 336-342.

Markan KR, Naber MC, Ameka MK, Anderegg MD, Mangelsdorf DJ, Kliewer SA, Mohammadi M \& Potthoff MJ 2014 Circulating FGF21 is liver derived and enhances glucose uptake during refeeding and overfeeding. Diabetes 63 4057-4063. (doi:10.2337/db14-0595)

Meier JJ 2012 GLP-1 receptor agonists for individualized treatment of type 2 diabetes mellitus. Nature Reviews. Endocrinology 8 728-742. (doi:10.1038/nrendo.2012.140)

Michelotti GA, Machado MV \& Diehl AM 2013 NAFLD, NASH and liver cancer. Nature Reviews. Gastroenterology \& Hepatology 10 656-665. (doi:10.1038/nrgastro.2013.183)

Miller RA, Chu Q, Xie J, Foretz M, Viollet B \& Birnbaum MJ 2013 Biguanides suppress hepatic glucagon signalling by decreasing production of cyclic AMP. Nature 494 256-260. (doi:10.1038/nature11808)

Milne JC, Lambert PD, Schenk S, Carney DP, Smith JJ, Gagne DJ, Jin L, Boss O, Perni RB, Vu CB et al. 2007 Small molecule activators of SIRT1 as therapeutics for the treatment of type 2 diabetes. Nature $\mathbf{4 5 0} 712-716$. (doi:10.1038/nature06261)

Muise ES, Azzolina B, Kuo DW, El-Sherbeini M, Tan Y, Yuan X, Mu J, Thompson JR, Berger JP \& Wong KK 2008 Adipose fibroblast growth factor 21 is up-regulated by peroxisome proliferator-activated receptor $\gamma$ and altered metabolic states. Molecular Pharmacology 74 403-412. (doi:10.1124/mol.108.044826) 
Nawrocki AR, Rajala MW, Tomas E, Pajvani UB, Saha AK, Trumbauer ME, Pang Z, Chen AS, Ruderman NB, Chen H et al. 2006 Mice lacking adiponectin show decreased hepatic insulin sensitivity and reduced responsiveness to peroxisome proliferator-activated receptor $\gamma$ agonists. Journal of Biological Chemistry 281 2654-2660. (doi:10.1074/jbc. M505311200)

Nishimura T, Nakatake Y, Konishi M \& Itoh N 2000 Identification of a novel FGF, FGF-21, preferentially expressed in the liver. Biochimica et Biophysica Acta 1492 203-206. (doi:10.1016/S0167-4781(00)00067-1)

Nonogaki K, Hazama M \& Satoh N 2014 Liraglutide suppresses obesity and hyperglycemia associated with increases in hepatic fibroblast growth factor 21 production in KKAy mice. BioMed Research International 2014 751930. (doi:10.1155/2014/751930)

Nygaard EB, Vienberg SG, Orskov C, Hansen HS \& Andersen B 2012 Metformin stimulates FGF21 expression in primary hepatocytes. Experimental Diabetes Research 2012 465282. (doi:10.1155/2012/ 465282)

Orentreich N, Matias JR, DeFelice A \& Zimmerman JA 1993 Low methionine ingestion by rats extends life span. Journal of Nutrition 123 269-274.

Ouchi N, Parker JL, Lugus JJ \& Walsh K 2011 Adipokines in inflammation and metabolic disease. Nature Reviews. Immunology 11 85-97. (doi:10.1038/nri2921)

Owen BM, Bookout AL, Ding X, Lin VY, Atkin SD, Gautron L, Kliewer SA \& Mangelsdorf DJ 2013 FGF21 contributes to neuroendocrine control of female reproduction. Nature Medicine 19 1153-1156. (doi:10.1038/nm. 3250)

Owen BM, Ding X, Morgan DA, Coate KC, Bookout AL, Rahmouni K, Kliewer SA \& Mangelsdorf DJ 2014 FGF21 acts centrally to induce sympathetic nerve activity, energy expenditure, and weight loss. Cell Metabolism 20 670-677. (doi:10.1016/j.cmet.2014.07.012)

Owen BM, Mangelsdorf DJ \& Kliewer SA 2015 Tissue-specific actions of the metabolic hormones FGF15/19 and FGF21. Trends in Endocrinology and Metabolism 26 22-29. (doi:10.1016/j.tem.2014.10.002)

Park KG, Min AK, Koh EH, Kim HS, Kim MO, Park HS, Kim YD, Yoon TS, Jang BK, Hwang JS et al. 2008 Alpha-lipoic acid decreases hepatic lipogenesis through adenosine monophosphate-activated protein kinase (AMPK)-dependent and AMPK-independent pathways. Hepatology 48 1477-1486. (doi:10.1002/hep.22496)

Pedersen BK \& Febbraio MA 2012 Muscles, exercise and obesity: skeletal muscle as a secretory organ. Nature Reviews. Endocrinology 8 457-465. (doi:10.1038/nrendo.2012.49)

Petrovic N, Walden TB, Shabalina IG, Timmons JA, Cannon B \& Nedergaard J 2010 Chronic peroxisome proliferator-activated receptor $\gamma(\operatorname{PPAR} \gamma)$ activation of epididymally derived white adipocyte cultures reveals a population of thermogenically competent, UCP1-containing adipocytes molecularly distinct from classic brown adipocytes. Journal of Biological Chemistry 285 7153-7164. (doi:10.1074/jbc.M109.053942)

Planavila A, Redondo I, Hondares E, Vinciguerra M, Munts C, Iglesias R, Gabrielli LA, Sitges M, Giralt M, van Bilsen M et al. 2013 Fibroblast growth factor 21 protects against cardiac hypertrophy in mice. Nature Communications 4 2019. (doi:10.1038/ncomms3019)

Planavila A, Redondo-Angulo I, Ribas F, Garrabou G, Casademont J, Giralt M \& Villarroya F 2015 Fibroblast growth factor 21 protects the heart from oxidative stress. Cardiovascular Research 106 19-31. (doi:10.1093/cvr/ cvu263)

Pocai A, Carrington PE, Adams JR, Wright M, Eiermann G, Zhu L, Du X, Petrov A, Lassman ME, Jiang G et al. 2009 Glucagon-like peptide 1/glucagon receptor dual agonism reverses obesity in mice. Diabetes $\mathbf{5 8}$ 2258-2266. (doi:10.2337/db09-0278)

Ponugoti B, Kim DH, Xiao Z, Smith Z, Miao J, Zang M, Wu SY, Chiang CM, Veenstra TD \& Kemper JK 2010 SIRT1 deacetylates and inhibits SREBP$1 \mathrm{C}$ activity in regulation of hepatic lipid metabolism. Journal of Biological Chemistry 285 33959-33970. (doi:10.1074/jbc.M110.122978)

Potthoff MJ, Inagaki T, Satapati S, Ding X, He T, Goetz R, Mohammadi M, Finck BN, Mangelsdorf DJ, Kliewer SA et al. 2009 FGF21 induces PGC-1 $\alpha$ and regulates carbohydrate and fatty acid metabolism during the adaptive starvation response. PNAS 106 10853-10858. (doi:10.1073/ pnas.0904187106)

Prieur X, Mok CY, Velagapudi VR, Nunez V, Fuentes L, Montaner D, Ishikawa K, Camacho A, Barbarroja N, O'Rahilly S et al. 2011 Differential lipid partitioning between adipocytes and tissue macrophages modulates macrophage lipotoxicity and M2/M1 polarization in obese mice. Diabetes 60 797-809. (doi:10.2337/db10-0705)

Prip-Buus C, Pegorier JP, Duee PH, Kohl C \& Girard J 1990 Evidence that the sensitivity of carnitine palmitoyltransferase I to inhibition by malonylCoA is an important site of regulation of hepatic fatty acid oxidation in the fetal and newborn rabbit. Perinatal development and effects of pancreatic hormones in cultured rabbit hepatocytes. Biochemical Journal 269 409-415.

Qiang L, Wang L, Kon N, Zhao W, Lee S, Zhang Y, Rosenbaum M, Zhao Y, $\mathrm{Gu}$ W, Farmer SR et al. 2012 Brown remodeling of white adipose tissue by SirT1-dependent deacetylation of Ppar $\gamma$. Cell 150 620-632. (doi:10.1016/j.cell.2012.06.027)

Qiao L \& Shao J 2006 SIRT1 regulates adiponectin gene expression through Foxo1-C/enhancer-binding protein $\alpha$ transcriptional complex. Journal of Biological Chemistry 281 39915-39924. (doi:10.1074/jbc. M607215200)

Sadry SA \& Drucker DJ 2013 Emerging combinatorial hormone therapies for the treatment of obesity and T2DM. Nature Reviews. Endocrinology 9 425-433. (doi:10.1038/nrendo.2013.47)

Samson SL, Sathyanarayana P, Jogi M, Gonzalez EV, Gutierrez A, Krishnamurthy R, Muthupillai R, Chan L \& Bajaj M 2011 Exenatide decreases hepatic fibroblast growth factor 21 resistance in nonalcoholic fatty liver disease in a mouse model of obesity and in a randomised controlled trial. Diabetologia 54 3093-3100. (doi:10.1007) s00125-011-2317-z)

Schug TT, Xu Q, Gao H, Peres-da-Silva A, Draper DW, Fessler MB, Purushotham A \& Li X 2010 Myeloid deletion of SIRT1 induces inflammatory signaling in response to environmental stress. Molecular and Cellular Biology 30 4712-4721. (doi:10.1128/MCB.00657-10)

Shaw RJ, Lamia KA, Vasquez D, Koo SH, Bardeesy N, Depinho RA, Montminy M \& Cantley LC 2005 The kinase LKB1 mediates glucose homeostasis in liver and therapeutic effects of metformin. Science $\mathbf{3 1 0}$ 1642-1646. (doi:10.1126/science.1120781)

Shay KP, Moreau RF, Smith EJ, Smith AR \& Hagen TM 2009 Alpha-lipoic acid as a dietary supplement: molecular mechanisms and therapeutic potential. Biochimica et Biophysica Acta 1790 1149-1160. (doi:10.1016/ j.bbagen.2009.07.026)

Shimano M, Ouchi N \& Walsh K 2012 Cardiokines: recent progress in elucidating the cardiac secretome. Circulation 126 e327-e332. (doi:10.1161/CIRCULATIONAHA.112.150656)

Shin NR, Lee JC, Lee HY, Kim MS, Whon TW, Lee MS \& Bae JW 2014 An increase in the Akkermansia spp. population induced by metformin treatment improves glucose homeostasis in diet-induced obese mice. Gut 63 727-735. (doi:10.1136/gutjnl-2012-303839)

Slavin BG, Ong JM \& Kern PA 1994 Hormonal regulation of hormonesensitive lipase activity and mRNA levels in isolated rat adipocytes. Journal of Lipid Research 35 1535-1541.

So WY, Cheng Q, Chen L, Evans-Molina C, Xu A, Lam KS \& Leung PS 2013 High glucose represses $\beta$-klotho expression and impairs fibroblast growth factor 21 action in mouse pancreatic islets: involvement of peroxisome proliferator-activated receptor $\gamma$ signaling. Diabetes 62 3751-3759. (doi:10.2337/db13-0645)

So WY, Cheng Q, Xu A, Lam KS \& Leung PS 2015 Loss of fibroblast growth factor 21 action induces insulin resistance, pancreatic islet hyperplasia and dysfunction in mice. Cell Death \& Disease 6 e1707. (doi:10.1038/ cddis.2015.80)

Soccio RE, Chen ER \& Lazar MA 2014 Thiazolidinediones and the promise of insulin sensitization in type 2 diabetes. Cell Metabolism 20 573-591. (doi:10.1016/j.cmet.2014.08.005) 
Srinivasa S, Wong K, Fitch KV, Wei J, Petrow E, Cypess AM, Torriani M \& Grinspoon SK 2015 Effects of lifestyle modification and metformin on irisin and FGF21 among HIV-infected subjects with the metabolic syndrome. Clinical Endocrinology 82 678-685. (doi:10.1111/cen.12582)

Stefan N \& Haring HU 2013 The role of hepatokines in metabolism. Nature Reviews. Endocrinology 9 144-152. (doi:10.1038/nrendo.2012.258)

Stein S, Bachmann A, Lossner U, Kratzsch J, Bluher M, Stumvoll M \& Fasshauer M 2009 Serum levels of the adipokine FGF21 depend on renal function. Diabetes Care 32 126-128. (doi:10.2337/dc08-1054)

Suomalainen A, Elo JM, Pietilainen KH, Hakonen AH, Sevastianova K, Korpela M, Isohanni P, Marjavaara SK, Tyni T, Kiuru-Enari S et al. 2011 FGF-21 as a biomarker for muscle-manifesting mitochondrial respiratory chain deficiencies: a diagnostic study. Lancet. Neurology $\mathbf{1 0}$ 806-818. (doi:10.1016/S1474-4422(11)70155-7)

Tan TM, Field BC, McCullough KA, Troke RC, Chambers ES, Salem V, Gonzalez Maffe J, Baynes KC, De Silva A, Viardot A et al. 2013 Coadministration of glucagon-like peptide-1 during glucagon infusion in humans results in increased energy expenditure and amelioration of hyperglycemia. Diabetes 62 1131-1138. (doi:10.2337/db12-0797)

Tanaka N, Takahashi S, Zhang Y, Krausz KW, Smith PB, Patterson AD \& Gonzalez FJ 2015 Role of fibroblast growth factor 21 in the early stage of NASH induced by methionine- and choline-deficient diet. Biochimica et Biophysica Acta 1852 1242-1252. (doi:10.1016/j.bbadis.2015.02.012)

Timmers S, Konings E, Bilet L, Houtkooper RH, van de Weijer T, Goossens GH, Hoeks J, van der Krieken S, Ryu D, Kersten S et al. 2011 Calorie restriction-like effects of 30 days of resveratrol supplementation on energy metabolism and metabolic profile in obese humans. Cell Metabolism 14 612-622. (doi:10.1016/j.cmet.2011.10.002)

Tyynismaa H, Carroll CJ, Raimundo N, Ahola-Erkkila S, Wenz T, Ruhanen H, Guse K, Hemminki A, Peltola-Mjosund KE, Tulkki V et al. 2010 Mitochondrial myopathy induces a starvation-like response. Human Molecular Genetics 19 3948-3958. (doi:10.1093/hmg/ddq310)

Uebanso T, Taketani Y, Yamamoto H, Amo K, Ominami H, Arai H, Takei Y, Masuda M, Tanimura A, Harada N et al. 2011 Paradoxical regulation of human FGF21 by both fasting and feeding signals: is FGF21 a nutritional adaptation factor? PLOS ONE 6 e22976. (doi:10.1371/ journal.pone.0022976)

Unger RH \& Cherrington AD 2012 Glucagonocentric restructuring of diabetes: a pathophysiologic and therapeutic makeover. Journal of Clinical Investigation 122 4-12. (doi:10.1172/JCI60016)

Vernochet C, Peres SB, Davis KE, McDonald ME, Qiang L, Wang H, Scherer PE \& Farmer SR $2009 \mathrm{C} / \mathrm{EBP} \alpha$ and the corepressors CtBP1 and CtBP2 regulate repression of select visceral white adipose genes during induction of the brown phenotype in white adipocytes by peroxisome proliferator-activated receptor $\gamma$ agonists. Molecular and Cellular Biology 29 4714-4728. (doi:10.1128/MCB.01899-08)

Vetterli L, Brun T, Giovannoni L, Bosco D \& Maechler P 2011 Resveratro potentiates glucose-stimulated insulin secretion in INS-1E $\beta$-cells and human islets through a SIRT1-dependent mechanism. Journal of Biological Chemistry 286 6049-6060. (doi:10.1074/jbc.M110.176842)

Wei W, Dutchak PA, Wang X, Ding X, Bookout AL, Goetz R, Mohammadi M, Gerard RD, Dechow PC, Mangelsdorf DJ et al. 2012 Fibroblast growth factor 21 promotes bone loss by potentiating the effects of peroxisome proliferator-activated receptor $\gamma$. PNAS 109 3143-3148. (doi:10.1073/pnas.1200797109)
Wente W, Efanov AM, Brenner M, Kharitonenkov A, Koster A, Sandusky GE, Sewing S, Treinies I, Zitzer H \& Gromada J 2006 Fibroblast growth factor-21 improves pancreatic $\beta$-cell function and survival by activation of extracellular signal-regulated kinase $1 / 2$ and Akt signaling pathways. Diabetes 55 2470-2478. (doi:10.2337/db05-1435)

Wu AL, Kolumam G, Stawicki S, Chen Y, Li J, Zavala-Solorio J, Phamluong K, Feng B, Li L, Marsters S et al. 2011 Amelioration of type 2 diabetes by antibody-mediated activation of fibroblast growth factor receptor 1 . Science Translational Medicine 3 113ra126. (doi:10.1126/scitranslmed. 3002669)

Wu X, Qi YF, Chang JR, Lu WW, Zhang JS, Wang SP, Cheng SJ, Zhang M, Fan Q, Lv Y et al. 2014 Possible role of fibroblast growth factor 21 on atherosclerosis via amelioration of endoplasmic reticulum stressmediated apoptosis in apoE mice. Heart and Vessels [in press]. (doi:10.1007/s00380-014-0557-9)

Xu J, Lloyd DJ, Hale C, Stanislaus S, Chen M, Sivits G, Vonderfecht S, Hecht R, Li YS, Lindberg RA et al. 2009 Fibroblast growth factor 21 reverses hepatic steatosis, increases energy expenditure, and improves insulin sensitivity in diet-induced obese mice. Diabetes 58 250-259. (doi:10.2337/db08-0392)

Yang C, Lu W, Lin T, You P, Ye M, Huang Y, Jiang X, Wang C, Wang F, Lee MH et al. 2013 Activation of liver FGF21 in hepatocarcinogenesis and during hepatic stress. BMC Gastroenterology 13 67. (doi:10.1186/ 1471-230X-13-67)

Yang Y, Li W, Liu Y, Sun Y, Li Y, Yao Q, Li J, Zhang Q, Gao Y, Gao L et al. 2014 Alpha-lipoic acid improves high-fat diet-induced hepatic steatosis by modulating the transcription factors SREBP-1, FoxO1 and Nrf2 via the SIRT1/LKB1/AMPK pathway. Journal of Nutritional Biochemistry 25 1207-1217. (doi:10.1016/j.jnutbio.2014.06.001)

Yu J, Zhao L, Wang A, Eleswarapu S, Ge X, Chen D \& Jiang H 2012 Growth hormone stimulates transcription of the fibroblast growth factor 21 gene in the liver through the signal transducer and activator of transcription 5. Endocrinology 153 750-758. (doi:10.1210/en.2011-1591)

Zhang Y, Lei T, Huang JF, Wang SB, Zhou LL, Yang ZQ \& Chen XD 2011 The link between fibroblast growth factor 21 and sterol regulatory element binding protein 1c during lipogenesis in hepatocytes. Molecular and Cellular Endocrinology 342 41-47. (doi:10.1016/j.mce.2011.05.003)

Zhang Y, Xie Y, Berglund ED, Coate KC, He TT, Katafuchi T, Xiao G, Potthoff MJ, Wei W, Wan Y et al. 2012 The starvation hormone, fibroblast growth factor-21, extends lifespan in mice. eLife $\mathbf{1}$ e00065. (doi:10.7554/eLife.00065)

Zhang C, Shao M, Yang H, Chen L, Yu L, Cong W, Tian H, Zhang F, Cheng P, Jin L et al. 2013a Attenuation of hyperlipidemia- and diabetes-induced early-stage apoptosis and late-stage renal dysfunction via administration of fibroblast growth factor-21 is associated with suppression of renal inflammation. PLOS ONE 8 e82275. (doi:10.1371/journal.pone. 0082275)

Zhang M, Liu Y, Xiong ZY, Deng ZY, Song HL \& An ZM 2013b Changes of plasma fibroblast growth factor-21 (FGF-21) in oral glucose tolerance test and effects of metformin on FGF-21 levels in type 2 diabetes mellitus. Endokrynologia Polska 64 220-224.

Zhu W, Wang C, Liu L, Li Y, Li X, Cai J \& Wang H 2014 Effects of fibroblast growth factor 21 on cell damage in vitro and atherosclerosis in vivo. Canadian Journal of Physiology and Pharmacology 92 927-935. (doi:10.1139/cjpp-2014-0227)

Received in final form 17 May 2015

Accepted 1 June 2015 http://joe.endocrinology-journals.org

DOI: 10.1530/JOE-15-0160
(C) 2015 Society for Endocrinology Printed in Great Britain
Published by Bioscientifica Ltd. 